\title{
Quantifying soil carbon accumulation in Alaskan terrestrial ecosystems during the last 15000 years
}

\author{
Sirui Wang ${ }^{1}$, Qianlai Zhuang ${ }^{1,2}$, and Zicheng $\mathbf{Y u}^{3}$ \\ ${ }^{1}$ Department of Earth, Atmospheric, and Planetary Sciences, Purdue University, West Lafayette, Indiana 47907, USA \\ ${ }^{2}$ Department of Agronomy, Purdue University, West Lafayette, Indiana 47907, USA \\ ${ }^{3}$ Department of Earth and Environmental Sciences, Lehigh University, Bethlehem, Pennsylvania 18015, USA
}

Correspondence to: Qianlai Zhuang (qzhuang@ purdue.edu)

Received: 7 July 2016 - Published in Biogeosciences Discuss.: 14 July 2016

Revised: 10 November 2016 - Accepted: 10 November 2016 - Published: 25 November 2016

\begin{abstract}
Northern high latitudes contain large amounts of soil organic carbon (SOC), of which Alaskan terrestrial ecosystems account for a substantial proportion. In this study, the SOC accumulation in Alaskan terrestrial ecosystems over the last 15000 years was simulated using a process-based biogeochemistry model for both peatland and non-peatland ecosystems. Comparable with the previous estimates of 25 $70 \mathrm{PgC}$ in peatland and $13-22 \mathrm{PgC}$ in non-peatland soils within $1 \mathrm{~m}$ depth in Alaska using peat-core data, our model estimated a total SOC of $36-63 \mathrm{PgC}$ at present, including $27-48 \mathrm{Pg} \mathrm{C}$ in peatland soils and $9-15 \mathrm{Pg} \mathrm{C}$ in non-peatland soils. Current vegetation stored 2.5-3.7 Pg C in Alaska, with $0.3-0.6 \mathrm{Pg} \mathrm{C}$ in peatlands and $2.2-3.1 \mathrm{Pg} \mathrm{C}$ in non-peatlands. The simulated average rate of peat $\mathrm{C}$ accumulation was $2.3 \mathrm{TgC} \mathrm{yr}^{-1}$, with a peak value of $5.1 \mathrm{TgC}^{-1}$ during the Holocene Thermal Maximum (HTM) in the early Holocene,

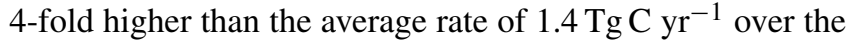
rest of the Holocene. The SOC accumulation slowed down, or even ceased, during the neoglacial climate cooling after the mid-Holocene, but increased again in the 20th century. The model-estimated peat depths ranged from 1.1 to $2.7 \mathrm{~m}$, similar to the field-based estimate of $2.29 \mathrm{~m}$ for the region. We found that the changes in vegetation and their distributions were the main factors in determining the spatial variations of SOC accumulation during different time periods. Warmer summer temperature and stronger radiation seasonality, along with higher precipitation in the HTM and the 20th century, might have resulted in the extensive peatland expansion and carbon accumulation.
\end{abstract}

\section{Introduction}

Global surface air temperature has been increasing since the middle of the 19th century (Jones and Mogberg, 2003; Manabe and Wetherald, 1980, 1986). Since 1970, the warming trend has accelerated at a rate of $0.35^{\circ}$ decade $^{-1}$ in northern high latitudes (Euskirchen et al., 2007; McGuire et al., 2009). It is predicted that the warming will continue in the next 100 years (Juday, 2005; Intergovernmental Panel on Climate Change (IPCC), 2013, 2014). The land surface in northern high latitudes $\left(>45^{\circ} \mathrm{N}\right)$ occupies $22 \%$ of the global surface and stores over $40 \%$ of the global soil organic carbon (SOC) (McGuire et al., 1995; Melillo et al., 1995; McGuire and Hobbie, 1997). Specifically, the northern high latitudes were estimated to store $200-600 \mathrm{Pg} \mathrm{C}\left(1 \mathrm{Pg} \mathrm{C}=10^{15} \mathrm{~g} \mathrm{C}\right)$ in peatland soils depending on the depth considered (Gorham, 1990, 1991; Yu, 2012), $750 \mathrm{Pg} \mathrm{C}$ in non-peatland soils (within $3 \mathrm{~m}$ ) (Schuur et al., 2008; Tarnocai et al., 2009; Hugelius et al., 2014), and an additional $400 \mathrm{Pg} \mathrm{C}$ in frozen loess deposits of Siberia (Zimov et al., 2006). Peatland area is around 40 million hectares in Alaska compared with total 350 million hectares in northern high latitudes (Kivinen and Pakarinen, 1981). Alaskan peatlands account for the most peatland area in the USA and cover at least $8 \%$ of the total land area (Bridgham et al., 2006). To date, the regional soil $\mathrm{C}$ and its responses to the climate change are still with large uncertainties (McGuire et al., 2009; Loisel et al., 2014).

The warming climate could increase $\mathrm{C}$ input to soils as litters by stimulating plant net primary productivity (NPP) (Loisel et al., 2012). However, it can also decrease the SOC by increasing soil respiration (Yu et al., 2009). Warming can 


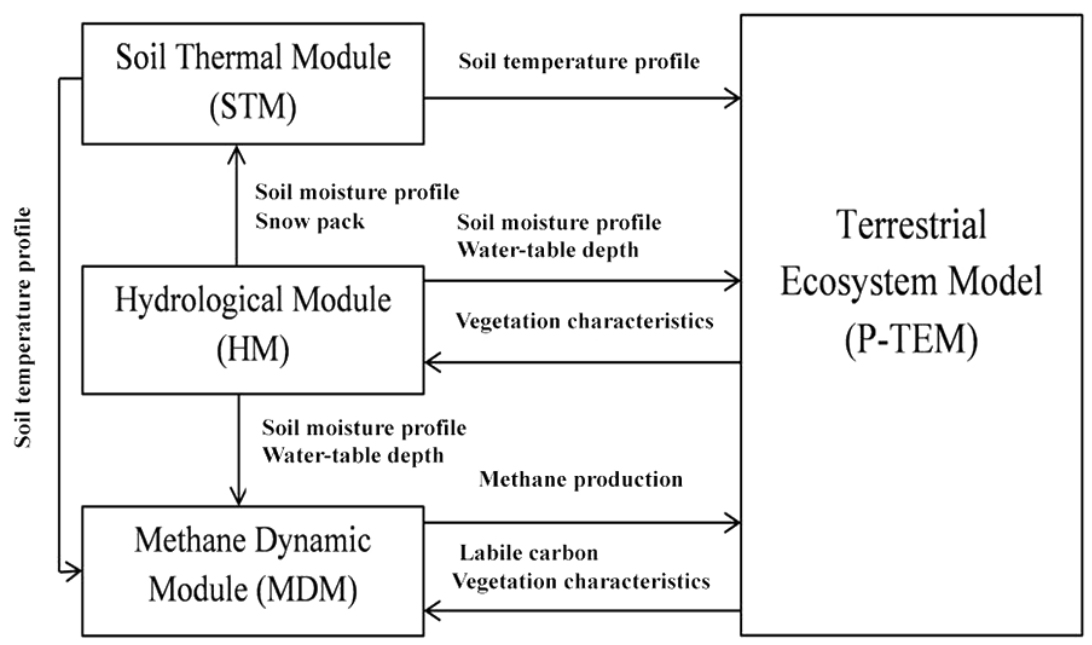

Figure 1. The P-TEM (Peatland-Terrestrial Ecosystem Model) framework includes a soil thermal module (STM), a hydrologic module (HM), a carbon/nitrogen dynamic model (CNDM), and a methane dynamics module (MDM) (Wang et al., 2016).

also draw down the water table in peatlands by increasing evapotranspiration, resulting in higher decomposition as the aerobic respiration has a higher rate than anaerobic respiration in general (Hobbie et al., 2000). SOC accumulates where the rate of soil $\mathrm{C}$ input is higher than decomposition. The variation of climate may switch the role of soils between a $\mathrm{C}$ sink and a C source (Davidson and Janssens, 2006; Davidson et al., 2000; Jobbágy and Jackson, 2000). Unfortunately, due to the data gaps of field measurement and uncertainties in estimating regional $\mathrm{C}$ stock (Yu, 2012), with limited understanding of both peatlands and non-peatlands and their responses to climate change, there is no consensus on the sink and source activities of these ecosystems (Frolking et al., 2011; Belyea, 2009; McGuire et al., 2009).

Both observation and model simulation studies have been applied to understand the long-term peat $\mathrm{C}$ accumulation in northern high latitudes. Most field estimations are based on series of peat-core samples (Turunen et al., 2002; Roulet et al., 2007; Yu et al., 2009; Tarnocai et al., 2009). However, those core analyses may not be adequate for estimating the regional $\mathrm{C}$ accumulation due to their limited spatial coverage. To date, a number of model simulations have also been carried out. For instance, Frolking et al. (2010) developed a peatland model considering the effects of plant community, hydrological dynamics and peat properties on SOC accumulation. The simulated results were compared with peatcore data. They further analyzed the contributions of different plant functional types (PFTs) to the peat $\mathrm{C}$ accumulation. However, this 1-D model has not been evaluated with respect to soil moisture, water-table depth, methane fluxes, and carbon and nitrogen fluxes and has not been used in large spatial-scale simulations by considering other environmental factors (e.g., temperature, vapor pressure, and radiation). In contrast, Spahni et al. (2013) used a dynamic global vegetation and land surface process model (LPX), based on LPJ (Sitch et al., 2003), imbedded with a peatland module, which considered the nitrogen feedback on plant productivity (Xu-Ri and Prentice, 2008) and plant biogeography, to simulate the SOC accumulation rates of northern peatlands. However, climatic effects on SOC were not fully explained, presumably due to its inadequate representation of ecosystem processes (Stocker et al., 2011, 2014; Kleinen et al., 2012). The Terrestrial Ecosystem Model (TEM) has been applied to study $\mathrm{C}$ and nitrogen dynamics in the Arctic (Zhuang et al., 2001, 2002, 2003, 2015; He et al., 2014). However, the model has not been calibrated and evaluated with peat-core $\mathrm{C}$ data, and has not been applied to investigate the regional peatland $\mathrm{C}$ dynamics. Building upon these efforts, recently we fully evaluated the peatland version of TEM (P-TEM) including modules of hydrology (HM), soil thermal (STM), C and nitrogen dynamics (CNDM) for both upland and peatland ecosystems (Wang et al., 2016).

Here we used the peatland-core data for various peatland ecosystems to parameterize and test P-TEM (Fig. 1). The model was then used to quantify soil $\mathrm{C}$ accumulation of both peatland and non-peatland ecosystems across the Alaskan landscape since the last deglaciation. This study is among the first to examine the peatland and non-peatland $\mathrm{C}$ dynamics and their distributions and peat depths using core data at regional scales.

\section{Methods}

\subsection{Overview}

To conduct regional simulations of carbon accumulation for both uplands and peatlands, we first parameterized the PTEM for representative ecosystems in Alaska. Second, we 
Table 1. Description of sites and variables used for parameterizing the core carbon and nitrogen module (CNDM).

\begin{tabular}{|c|c|c|c|}
\hline Site* & Vegetation & $\begin{array}{l}\text { Observed variables for CNDM } \\
\text { parameterization }\end{array}$ & References \\
\hline APEXCON & $\begin{array}{l}\text { Moderately rich open fen with sedges } \\
\text { (Carex sp.), spiked rushes (Eleocharis } \\
\text { sp.), Sphagnum spp., and brown mosses } \\
\text { (e.g., Drepanocladus aduncus) }\end{array}$ & $\begin{array}{l}\text { Mean annual aboveground } \\
\text { NPP in } 2009 \\
\text { Mean annual belowground } \\
\text { NPP in } 2009 \\
\text { Aboveground biomass in } \\
2009\end{array}$ & $\begin{array}{l}\text { Chivers et al. (2009), } \\
\text { Turetsky et al. (2008), } \\
\text { Kane et al. (2010), } \\
\text { Churchill et al. (2011) }\end{array}$ \\
\hline APEXPER & $\begin{array}{l}\text { Peat plateau bog with black spruce } \\
\text { (Picea mariana), Sphagnum spp., and } \\
\text { feather mosses }\end{array}$ & & \\
\hline
\end{tabular}

organized the regional vegetation and peatland distribution data, spatial basal age data for all peatland grid cells based on site-level soil core data, and climate data for each period during the Holocene. Finally, we conducted the regional simulations and sensitivity analysis.

\subsection{Model description}

In P-TEM (Wang et al., 2016), peatland soil organic C (SOC) accumulation is determined by the difference between NPP and aerobic and anaerobic decomposition. Peatlands accumulate $\mathrm{C}$ where NPP is greater than decomposition, resulting in positive net ecosystem production (NEP):

$\mathrm{NEP}=\mathrm{NPP}-R_{\mathrm{H}}-R_{\mathrm{CH}_{4}}-R_{\mathrm{CWM}}-R_{\mathrm{CM}}-R_{\mathrm{COM}}$.

P-TEM was developed based on the Terrestrial Ecosystem Model (TEM) at a monthly step (Zhuang et al., 2003, 2015). It explicitly considers the process of aerobic decomposition $\left(R_{\mathrm{H}}\right)$ related to the variability of water-table depth; net methane emission after methane oxidation $\left(R_{\mathrm{CH}_{4}}\right) ; \mathrm{CO}_{2}$ emission due to methane oxidation $\left(R_{\mathrm{CWM}}\right)$ (Zhuang et al., 2015); $\mathrm{CO}_{2}$ release accompanied by the methanogenesis $\left(R_{\mathrm{CM}}\right)$ (Tang et al., 2010; Conrad, 1999); and $\mathrm{CO}_{2}$ release from other anaerobic processes $\left(R_{\mathrm{COM}}\right.$, e.g., fermentation, terminal electron acceptor (TEA) reduction) (Keller and Bridgham, 2007; Keller and Takagi, 2013). For upland soils, we only considered the heterotrophic respiration under aerobic conditions (Raich et al., 1991). For a detailed model description, see Wang et al. (2016).

We modeled peatland soils as a two-layer system for a hydrological module (HM) while keeping the three-layer system for upland soils (Zhuang et al., 2002). The soil layers above the lowest water-table position are divided into (1) a moss (or litter) organic layer $(0-10 \mathrm{~cm})$ and (2) a humic organic layer $(10-30 \mathrm{~cm})$ (Wang et al., 2016). Based on the total amount of water content within those two unsaturated layers, the actual water-table depth (WTD) is estimated. The water content at each $1 \mathrm{~cm}$ above the water table can then be de- termined after solving the water balance equations (Zhuang et al., 2004).

In the STM module, the soil vertical profile is divided into four layers: (1) snowpack in winter, (2) a moss (or litter) organic layer, and (3) upper and (4) lower humic organic soil (Wang et al., 2016). Each of these soil layers is characterized by a distinct soil thermal conductivity and heat capacity. We used the observed water content to drive the STM (Zhuang et al., 2001).

The methane dynamics module (MDM) (Zhuang et al., 2004) considers the processes of methanogenesis, methanotrophy, and the transportation pathways, including (1) diffusion through the soil profile, (2) plant-aided transportation and (3) ebullition. The soil temperatures calculated from STM, after interpolation into $1 \mathrm{~cm}$ sub-layers, are input to the MDM. The water-table depth and soil water content in the unsaturated zone for methane production and emission are obtained from HM, and NPP is calculated from the CNDM. Soil-water $\mathrm{pH}$ is prescribed from observed data and the root distribution determines the redox potential (Zhuang et al., 2004).

\subsection{Model parameterization}

We have parameterized the key parameters of the individual modules, including HM, STM, and MDM in Wang et al. (2016). The parameters in CNDM for upland soils and vegetation have been optimized in the previous studies (Zhuang et al 2002, 2003; Tang and Zhuang, 2008). Here we parameterized P-TEM for peatland ecosystems using data from a moderately rich Sphagnum spp. open fen (APEXCON) and a Sphagnum-black spruce (Picea mariana) bog (APEXPER) (Table 1). Both are located in the Alaskan Peatland Experiment (APEX) study area, where Picea mariana is the only tree species above breast height in APEXPER. Three water-table position manipulations were established in APEX, including control, lowered, and raised water-table plots (Chivers et al., 2009; Turetsky et al., 2008; Kane et al., 
Table 2. Carbon pools and fluxes used for calibration of CMDM.

\begin{tabular}{lrr|rrl}
\hline & \multicolumn{2}{c|}{ Sphagnum open fen } & \multicolumn{2}{c}{ Sphagnum-black spruce bog } & \\
\cline { 2 - 4 } Annual carbon fluxes or pools* & Observation & Simulation & Observation & Simulation & References \\
\hline NPP & $445 \pm 260$ & 410 & $433 \pm 107$ & 390 & Turetsky et al. (2008), \\
Aboveground vegetation carbon & $149-287$ & & 423 & & Churchill (2011), \\
Belowground vegetation carbon & $347-669$ & & 987 & & Saarinen (1996), \\
Total vegetation carbon density & $496-856$ & 800 & 1410 & 1300 & Moore et al. (2002), \\
Litter fall carbon flux & 300 & 333 & 300 & 290 & Zhuang et al. (2002), \\
Methane emission flux & 19.5 & 19.2 & 9.7 & 12.8 & Tarnocai et al. (2009), \\
& & & & & Kuhry and Vitt (1996) \\
\hline
\end{tabular}

* Units for annual net primary production (NPP) and litter fall carbon are $\mathrm{g} \mathrm{Cm}^{-2} \mathrm{yr}^{-1}$. Units for vegetation carbon density are $\mathrm{g} \mathrm{C} \mathrm{m}^{-2}$. Units for methane emissions are $\mathrm{g} \mathrm{C}^{-} \mathrm{CH}_{4} \mathrm{~m}^{-2} \mathrm{yr}^{-1}$. The simulated total annual methane fluxes were compared with the observations at APEXCON in 2005 and SPRUCE in 2012. A ratio of 0.47 was used to convert vegetation biomass to carbon (Raich, 1991).

2010; Churchill et al., 2011). There were also several internal collapse scars that formed with thaw of surface permafrost, including non, old, and new collapse plots. APEXCON represents the control manipulation and APEXPER represents the non-collapse plot. The annual NPP and aboveground biomass at both sites were measured in 2009. There were no belowground observations at APEX, however, at a Canadian peatland, Mer Bleue, which includes Sphagnum spp. dominated bog (dominated by shrubs and Sphagnum) and pool fen (dominated by sedges and herbs and Sphagnum). The belowground biomass was also observed at Suurisuo mire complex, southern Finland, a sedge fen site dominated by Carex rostrate. We used the ratio ( $70 \%$ ) of belowground biomass to total biomass from these two study sites to calculate the missing belowground biomass values at APEXCON and APEXPER (Table 2). We conducted 100000 Monte Carlo ensemble simulations to calibrate the model for each site using a Bayesian approach, and parameter values with the modes in their posterior distributions were selected (Tang and Zhuang, 2008, 2009).

\subsection{Regional model input data}

The Alaskan C stock was simulated through the Holocene driven with vegetation data reconstructed for four time periods, including a time period encompassing a millennialscale warming event during the last deglaciation known as the Bølling-Allerød at $15-11 \mathrm{ka}(1 \mathrm{ka}=1000 \mathrm{cal} \mathrm{yr}$ before present), Holocene Thermal Maximum (HTM) during the early Holocene at 11-10 and 10-9 ka, and the mid (9-5 ka) and late Holocene (5 ka-1900 AD) (He et al., 2014). We used the modern vegetation distribution for the simulation during the period 1900-2000 AD (Fig. 2). We assumed that the vegetation distribution remained static within each corresponding time period. Upland ecosystems were classified into boreal deciduous broadleaf forest, boreal evergreen needleleaf and mixed forest, alpine tundra, wet tundra, and barren lands (Table 3). By using the same vegetation distribution map, we reclassified the upland ecosystems into two peat-

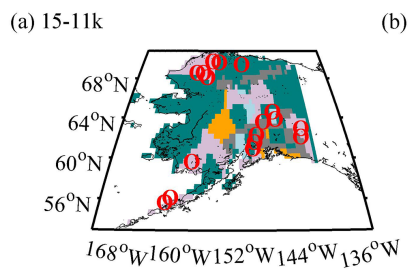

(b) $11-10 \mathrm{k}$

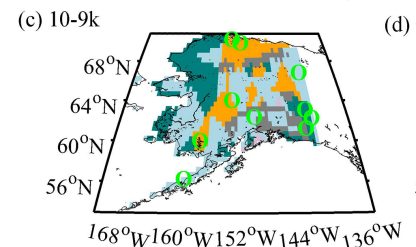

(e) $19-20$ th
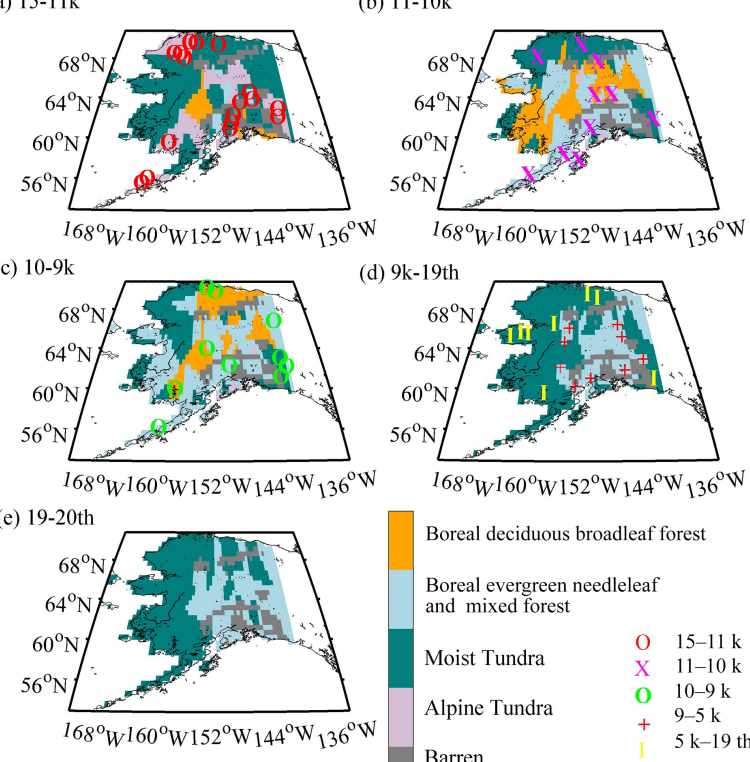

(d) $9 \mathrm{k}-19 \mathrm{th}$

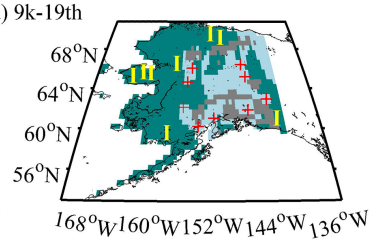

Boreal deciduous broadleaf forest

Boreal evergreen needleleaf and mixed forest

$\begin{array}{lll} & \mathrm{O} & 15-11 \mathrm{k}\end{array}$

Moist Tundra $\quad \mathrm{X} \quad 11-10 \mathrm{k}$

Alpine Tundra $\quad$ O $\quad 10-9 \mathrm{k}$

$\begin{array}{ll} & +9-5 \mathrm{k} \\ \text { Barren } & 5 \mathrm{k}-19 \text { th }\end{array}$

Figure 2. Alaskan vegetation distribution maps reconstructed from fossil pollen data during (a) 15-11 ka, (b) 11-10 ka, (c) 10-9 ka, (d) $9 \mathrm{ka}-1900 \mathrm{AD}$, and (e) 1900-2000 AD (He et al., 2014). Symbols represent the basal age of peat samples $(n=102)$ in Gorham et al. (2012). Each symbol indicates one to three peat samples in the map. Peat samples with basal age $9-5 \mathrm{k}$ and $5 \mathrm{k}-19$ th are shown in map (d) as there is no change in vegetation distribution during $9 \mathrm{k}-$ 19th. Barren refers to mountain range and large water body areas that can not be interpolated.

land types, including Sphagnum spp. poor fens (SP) dominated by tundra and Sphagnum spp.-black spruce (Picea mariana) bog/peatland (SBP) dominated by forest ecosystems (Table 3).

The upland and peatland ecosystem distribution for each grid cell was determined using the wetland inundation data extracted from the NASA/GISS global natural wetland 
Table 3. Assignment of biomized fossil pollen data to the vegetation types in TEM (He et al., 2014).

\begin{tabular}{lll}
\hline TEM upland vegetation & TEM peatland vegetation & BIOMISE code \\
\hline Alpine tundra & Sphagnum spp. open fen & CUSH DRYT PROS \\
$\begin{array}{l}\text { Moist tundra } \\
\text { Boreal evergreen needleleaf and mixed forest }\end{array}$ & Sphagnum-black spruce bog & DWAR SHRU \\
Boreal deciduous broadleaf forest & & CLDE COCO CLMX COMX \\
\hline
\end{tabular}

Table 4. Relations between peatland basal age and vegetation distribution.

\begin{tabular}{lll}
\hline Peatland basal age & Vegetation types & Location in Alaska \\
\hline $15-11 \mathrm{ka}$ & alpine tundra & $\begin{array}{l}\text { southern, northwestern, and southeastern } \\
\text { coasts } \\
\text { southern, northern, and southeastern coasts } \\
\text { eastern central part }\end{array}$ \\
& $\begin{array}{l}\text { moist tundra } \\
\text { boreal evergreen needleleaf forest } \\
\text { boreal deciduous broadleaf forest } \\
\text { moist tundra } \\
\text { boreal evergreen needleleaf forest } \\
\text { boreal deciduous broadleaf forest } \\
\text { moist tundra } \\
\text { boreal evergreen needleleaf forest } \\
\text { moist tundra }\end{array}$ & $\begin{array}{l}\text { southern and northern coasts } \\
\text { central part }\end{array}$ \\
& boreal evergreen needleleaf forest & central part \\
$5 \mathrm{ka}-1900 \mathrm{AD}$ & & western coast \\
\hline
\end{tabular}

dataset (Matthews and Fung, 1987). The resolution was resampled to $0.5^{\circ} \times 0.5^{\circ}$ from $1^{\circ} \times 1^{\circ}$. Given the same topography of Alaska during the Holocene, we assumed that the wetland distribution remained the same throughout the Holocene. The inundation fraction was assumed to be the same within each grid through time and the land grids not covered by peatland were treated as uplands. We calculated the total area of modern Alaskan peatlands to be $302410 \mathrm{~km}^{2}$, which was within the range from $132000 \mathrm{~km}^{2}$ (Bridgham et al., 2006) to $596000 \mathrm{~km}^{2}$ (Kivinen and Pakarinen, 1981). The soil water $\mathrm{pH}$ data were extracted from Carter and Scholes (2000), and the elevation data were derived from Zhuang et al. (2007).

Our regional simulations considered the effects of basal ages on carbon accumulation. To obtain the spatially explicit basal age data for all peatland grid cells, we first categorized the observed basal ages of peat samples from Gorham et al. (2012) into different time periods, including 15-11, 1110, 10-9, and 9 ka-19th (Fig. 2). For each time period, the areas dominated by different vegetation types were assigned with varying peatland basal ages. To do that, we examined the association of peat basal ages and vegetation types from peat-core data. For instance, we found that peatland initiations during 15-11 ka occurred in the regions that were dominated by alpine tundra at the southern, northwestern, and southeastern coasts. We thus assign the different peatland basal ages for the grid cells according to their vegetation types for each time slice (Table 4).
Climate data were bias-corrected from ECBilt-CLIO model output (Timm and Timmermann, 2007) to minimize the difference from CRU data (He et al., 2014). Climate fields include monthly precipitation, monthly air temperature, monthly net incoming solar radiation, and monthly vapor pressure at a resolution of $2.5^{\circ} \times 2.5^{\circ}$. We used the same time-dependent forcing atmospheric carbon dioxide concentration data for model input as were used in ECBilt-CLIO transient simulations from the Taylor Dome (Timm and Timmermann, 2007). The historical climate data used for the simulation through the 20th century were monthly CRU2.0 data (Mitchell et al., 2004).

\subsection{Simulations and sensitivity test}

Simulations for pixels located on the Kenai Peninsula from 15 to $5 \mathrm{ka}$ were first conducted with the parameterized model. The peat-core data from four peatlands on the Kenai Peninsula, Alaska (Jones and Yu, 2010; Yu et al., 2010) (Table 5; also see Table 3 in Wang et al., 2016) were used to compare with the simulations. The observed data include the peat depth, bulk density of both organic and inorganic matters at $1 \mathrm{~cm}$ interval, and age determinations. The simulated $\mathrm{C}$ accumulation rates represent the actual ("true") rates at different times in the past. However, the calculated accumulation rates from peat cores are considered "apparent" accumulation rates, as peat would continue to decompose since the time of formation until the present when the measurement was made (Yu, 2012). To facilitate comparison between simulated and observed accumulation rates, we converted the 
Table 5. Sites used for comparison of carbon accumulation rates between simulation and observation (Jones and Yu, 2010).

\begin{tabular}{llllllrrr}
\hline Site name & Location & $\begin{array}{l}\text { Peatland } \\
\text { type }\end{array}$ & Latitude & Longitude & $\begin{array}{l}\text { Dating } \\
\text { method }\end{array}$ & $\begin{array}{r}\text { No. of } \\
\text { dates }\end{array}$ & $\begin{array}{r}\text { Basal age } \\
(\text { cal yr BP })\end{array}$ & $\begin{array}{r}\text { Time-weighted Holocene } \\
\text { accumulation rates } \\
\left(\mathrm{g} \mathrm{C} \mathrm{m}^{-2} \mathrm{yr}^{-1}\right)\end{array}$ \\
\hline Kenai Gasfield & Alaska, USA & fen & $60^{\circ} 27^{\prime} \mathrm{N}$ & $151^{\circ} 14^{\prime} \mathrm{W}$ & AMS & 12 & 11408 & 13.1 \\
No Name Creek & Alaska, USA & fen & $60^{\circ} 38^{\prime} \mathrm{N}$ & $151^{\circ} 04^{\prime} \mathrm{W}$ & AMS & 11 & 11526 & 12.3 \\
Horsetrail fen & Alaska, USA & rich fen & $60^{\circ} 25^{\prime} \mathrm{N}$ & $150^{\circ} 54^{\prime} \mathrm{W}$ & AMS & 10 & 13614 & 10.7 \\
Swanson fen & Alaska, USA & poor fen & $60^{\circ} 47^{\prime} \mathrm{N}$ & $150^{\circ} 49^{\prime} \mathrm{W}$ & AMS & 9 & 14225 & 5.7 \\
\hline
\end{tabular}
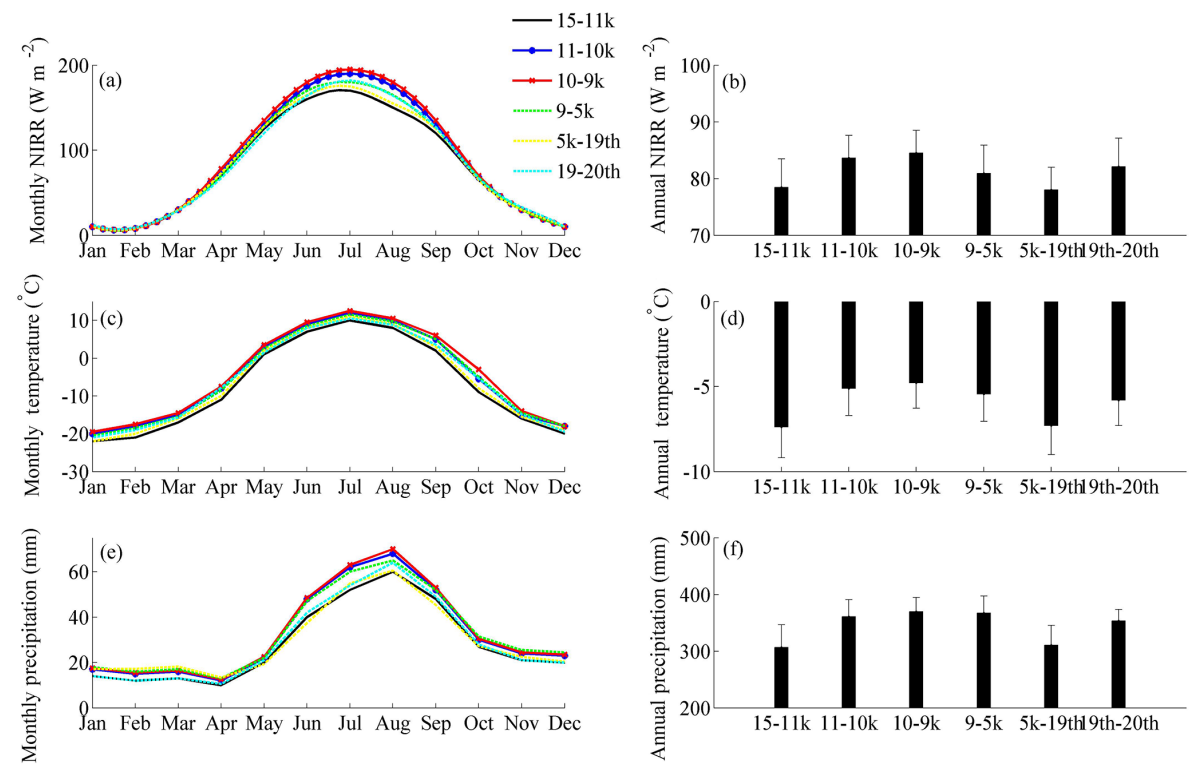

Figure 3. Simulated paleo-climate and other input data from $15 \mathrm{ka}$ to $2000 \mathrm{AD}$ : (a) mean monthly and (b) mean annual net incoming solar radiation (NIRR, $\mathrm{W} \mathrm{m}^{-2}$ ), (c) mean monthly and (d) mean annual air temperature $\left(^{\circ}\right)$, and (e) mean monthly and (f) mean annual precipitation (mm) (Timm and Timmermann, 2007; He et al., 2014).

simulated "true" accumulation rates to "apparent" rates, following the approach by Spahni et al. (2013). That is, we summed the annual net $\mathrm{C}$ accumulation over each 500-year interval and deducted the total amount of $\mathrm{C}$ decomposition from that time period, then dividing by 500 years.

Second, we conducted a transient regional simulation driven with monthly climatic data (Fig. 3) from $15 \mathrm{ka}$ to 2000 AD. The simulation was conducted assuming all grid cells were taken up by upland ecosystems to get the upland soil $\mathrm{C}$ spatial distributions during different time periods. We then conducted the second simulation assuming all grid cells were dominated by peatland ecosystems following Table 3 to obtain the distributions of peat SOC accumulation. Finally, we used the inundation fraction map to extract both uplands and peatlands and estimated the corresponding SOC stocks within each grid, which were then summed up to represent the Alaskan SOC stock. We also used the observed mean $\mathrm{C}$ content of $46.8 \%$ in peat mass and bulk density of $166 \pm 76 \mathrm{~kg} \mathrm{~m}^{-3}$ in Alaska (Loisel et al., 2014) to estimate peat depth distribution from the simulated peat SOC density $\left(\mathrm{kg} \mathrm{C} \mathrm{m}^{-2}\right)$.

Third, we conducted a series of extra simulations to further examine how uncertain climates and vegetation distribution affect our results. We used the original forcing data as the standard scenario and the warmer (monthly temperature $\left.+5^{\circ}\right)$ and cooler $\left(-5^{\circ}\right)$ as other two scenarios while keeping the rest of the forcing data unchanged. Similarly, we used the original forcing data as the standard scenario and the wetter (monthly precipitation $+10 \mathrm{~mm}$ ) and drier $(-10 \mathrm{~mm})$ to test the effect from precipitation. To further study whether vegetation distribution has stronger effects on SOC accumulation than climate in Alaska, we simply replaced SBP with SP and replaced the upland forests with tundra at the beginning of $15 \mathrm{ka}$. We then conducted the simulation under "warmer" and "wetter" conditions simultaneously as described before while keeping the vegetation distribution unchanged. 

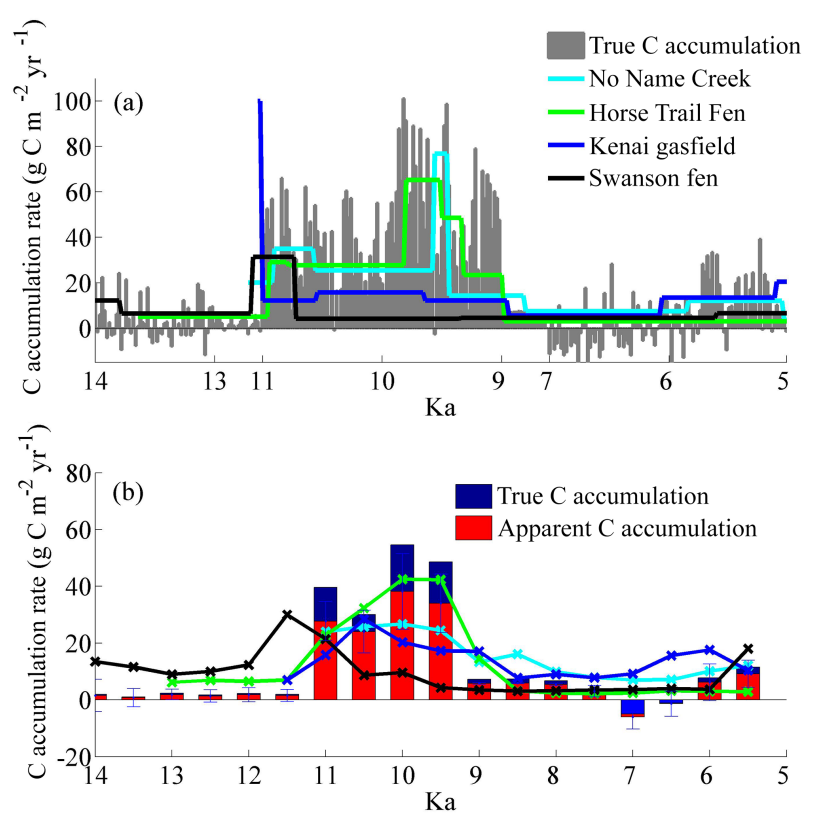

Figure 4. Simulated and observed carbon accumulation rates from 15 to $5 \mathrm{ka}$ in 20-year bins (a) and 500-year bins with standard deviation (b) for No Name Creek, Horse Trail Fen, Kenai Gasfield, and Swanson Fen. Peat-core data were from Jones and Yu (2010).

\section{Results and discussion}

\subsection{Simulated peatland carbon accumulation rates at site level}

Our paleosimulations showed a large peak of peat $\mathrm{C}$ accumulation rates at 11-9 ka during the HTM (Fig. 4). The simulated "true" and "apparent" rates captured this primary feature in peat-core data at almost all sites (Jones and Yu, 2010; see Wang et al., 2016, Table 3 for site details). We simulated an average of the peat SOC "apparent" accumulation rate of $11.4 \mathrm{~g} \mathrm{C} \mathrm{m}^{-2} \mathrm{yr}^{-1}$ from 15 to $5 \mathrm{ka}$, which was slightly higher than the observations at four sites $\left(10.45 \mathrm{~g} \mathrm{C} \mathrm{m}^{-2} \mathrm{yr}^{-1}\right)$. The simulated rate during the HTM was $26.5 \mathrm{~g} \mathrm{C} \mathrm{m}^{-2} \mathrm{yr}^{-1}$, up to 5 times higher than the rest of the Holocene $\left(5.04 \mathrm{~g} \mathrm{C} \mathrm{m}^{-2} \mathrm{yr}^{-1}\right)$. This corresponded to the observed average rate of $20 \mathrm{C} \mathrm{m}^{-2} \mathrm{yr}^{-1}$ from 11.5 to $8.6 \mathrm{ka}$, which is 4 times higher than $5 \mathrm{C} \mathrm{m}^{-2} \mathrm{yr}^{-1}$ over the rest of the Holocene.

\subsection{Vegetation carbon}

Model simulations showed an overall low vegetation $\mathrm{C}$ before the HTM (15-11 ka) (Fig. 5a) parallel to the relatively low annual and long-term NPP (Fig. 5b and c). The lowest amount of $\mathrm{C}\left(\sim 0.8 \mathrm{~kg} \mathrm{C} \mathrm{m}^{-2}\right)$ was stored in Sphagnumdominated peatland. Sphagnum-black spruce peatland also had low vegetation $\mathrm{C}$ density $\left(\sim 1 \mathrm{~kg} \mathrm{C} \mathrm{m}^{-2}\right)$. Upland vegetation showed a generally higher $\mathrm{C}$ storage, of which bo-

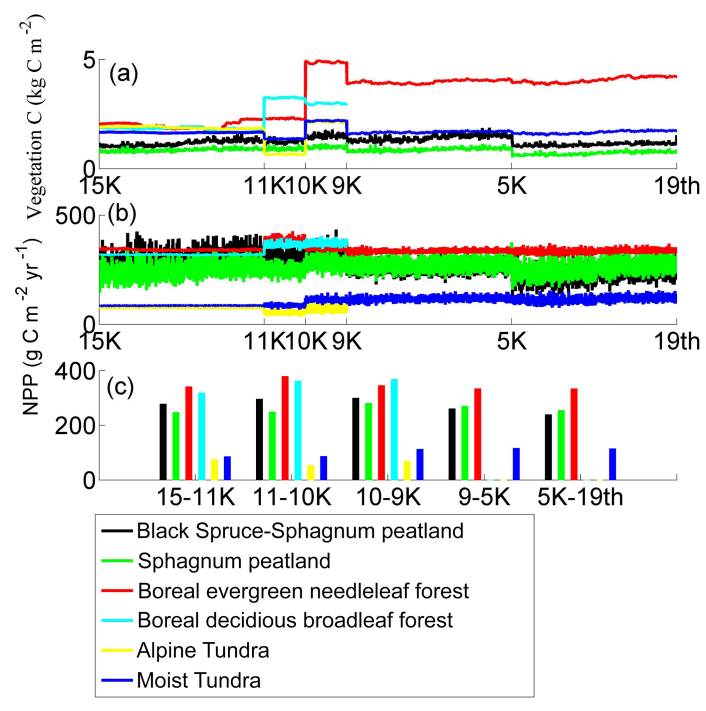

Figure 5. Simulated (a) mean vegetation carbon density $\left(\mathrm{kg} \mathrm{C} \mathrm{m}^{-2}\right)$ of different vegetation types, (b) annual NPP $\left(\mathrm{g} \mathrm{C} \mathrm{m}^{-2} \mathrm{yr}^{-1}\right)$, and (c) long-term NPP $\left(\mathrm{g} \mathrm{C} \mathrm{m}^{-2} \mathrm{yr}^{-1}\right)$.

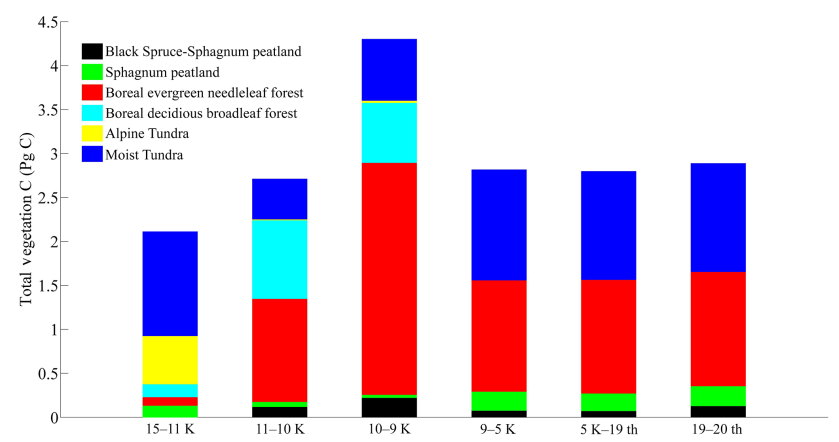

Figure 6. Total C (Pg C) stored in Alaskan vegetation for different time periods.

real evergreen needleleaf forest ranked first $\left(\sim 2 \mathrm{~kg} \mathrm{C} \mathrm{m}^{-2}\right)$. Highest NPP accompanied by highest vegetation carbon appeared during the HTM (11-9 ka) (Fig. 5a and b). Lower annual $\mathrm{C}$ uptake along with lower $\mathrm{C}$ was found during the mid and late Holocene (9 ka-19th), where peatland ecosystems exhibited the most obvious drops (Fig. 5a and b).

In general, vegetation held about $2 \mathrm{Pg} \mathrm{C}$ before the HTM (Fig. 6). Upland tundra ecosystems accounted for the highest amount of C. During the HTM, boreal evergreen needleleaf forest reached its peak and had an overwhelming proportion over total C. Similarly, a peak of total vegetation $\mathrm{C}$ appeared at the same time, averaging around $4.3 \mathrm{Pg} \mathrm{C}$. A large decrease occurred at the mid-Holocene and a slight decline continued till the late Holocene. We estimated a total of $2.9 \mathrm{Pg} \mathrm{C}$ stored in modern Alaskan vegetation, with $0.4 \mathrm{Pg}$ in peatlands and $2.5 \mathrm{Pg}$ in non-peatlands. The uncertainties during the model calibration (Table 2) resulted in 0.3-0.6 and 2.2-3.1 Pg C in peatlands (see Wang et al., 2016, for model parameters) 


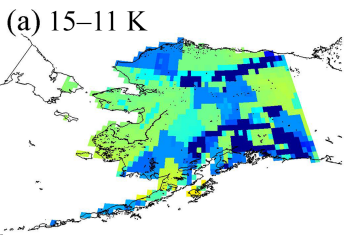

(c) $10-9 \mathrm{~K}$

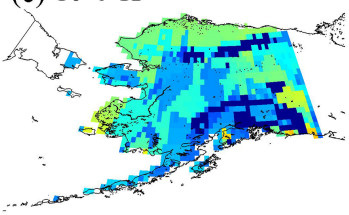

(e) $5 \mathrm{~K}-19$ th

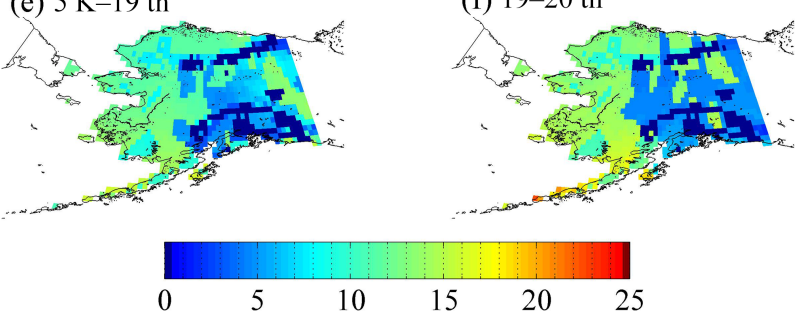

Figure 7. Average non-peatland (mineral) SOC density $\left(\mathrm{kg} \mathrm{C} \mathrm{m}^{-2}\right)$ during (a) 15-11 ka, (b) 11-10 ka, (c) 10-9 ka, (d) 9-5 ka, (e) $5 \mathrm{ka}-$ $1900 \mathrm{AD}$, and (f) 1900-2000 AD. The period of 9k-19th in Fig. 2d is separated into $9-5 \mathrm{k}$ and $5 \mathrm{k}-19$ th.

and non-peatland vegetation (see Tang and Zhuang, 2008, for uncertainty analyses for upland vegetation), respectively. Our estimation of 2.5-3.7 Pg C stored in the Alaskan vegetation was lower than the previous estimate of $5 \mathrm{Pg}$ (Balshi et al., 2007; McGuire et al., 2009), presumably due to the prior ranges of model parameters used from Tang and Zhuang (2008). Our overestimation of peatland area may also lead to a reduction of Alaskan non-peatland area.

\subsection{Soil carbon}

Carbon storage in Alaskan non-peatland soils varied spatially (Fig. 7). Moist tundra had the highest SOC density (12$25 \mathrm{~kg} \mathrm{C} \mathrm{m}^{-2}$ ), followed by deciduous broadleaf forest (8$13 \mathrm{~kg} \mathrm{C} \mathrm{m}^{-2}$ ) and evergreen needleleaf forest (3-8 $\mathrm{kg} \mathrm{C} \mathrm{m}^{-2}$ ) through all time slices between $15 \mathrm{ka}$ and $2000 \mathrm{AD}$. Dramatic changes in vegetation types have occurred in Alaska during different periods (Fig. 2). Before the HTM (15$11 \mathrm{ka}$ ), the terrestrial ecosystem was dominated by tundra. The northwestern coast and the eastern interior were covered by moist tundra. Southwestern Alaska and the interior south of the Brooks Range were dominated by alpine tundra (Fig. 2a). The basal ages of peat samples from Gorham et al. (2012) suggested that peatlands were likely to form from the (alpine) tundra ecosystems, although patches of boreal deciduous broadleaf forest and boreal evergreen needleleaf and mixed forest appeared at the north of the Alaska (a) $15-11 \mathrm{~K}$

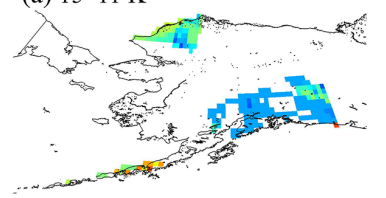

(c) $10-9 \mathrm{~K}$

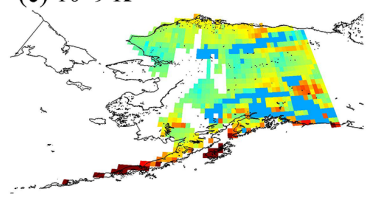

(e) $5 \mathrm{~K}-19$ th

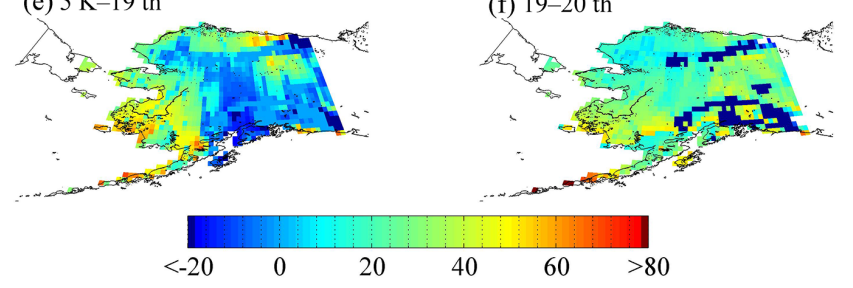

(b) $11-10 \mathrm{~K}$

(d) $9-5 \mathrm{~K}$

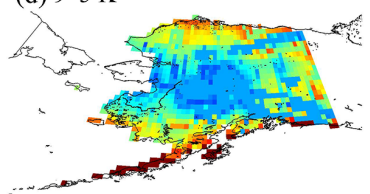

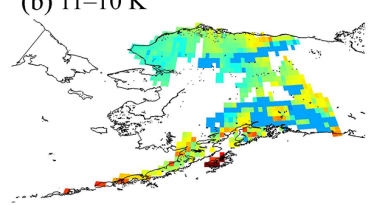

Figure 8. Peatland area expansion and peat soil $\mathrm{C}$ accumulation per 1000 years $\left(\mathrm{kg} \mathrm{C} \mathrm{m}^{-2} \mathrm{kyr}^{-1}\right)$ during (a) $15-11 \mathrm{ka}$, (b) $11-10 \mathrm{ka}$, (c) 10-9 ka, (d) 9-5 ka, (e) $5 \mathrm{ka}-1900 \mathrm{AD}$, and (f) 1900-2000 AD. The amount of $\mathrm{C}$ represents the $\mathrm{C}$ accumulation as the difference between the peat $\mathrm{C}$ amount in the final year and the first year in each time slice. The period of $9 \mathrm{k}-19$ th in Fig. $2 \mathrm{~d}$ is separated into $9-5 \mathrm{k}$ and $5 \mathrm{k}-19$ th.

Range. Initially, only Sphagnum open peatland (SP) existed, with less $\mathrm{C}\left(<10 \mathrm{~kg} \mathrm{C} \mathrm{m}^{-2}\right)$ sequestrated in the southeastern Brooks Range in comparison with southwestern and northwestern coastal parts (>15 $\mathrm{kg} \mathrm{C} \mathrm{m}^{-2}$ ) (Fig. 8a). Approximately $4.5 \times 10^{5} \mathrm{~km}^{2}$ area was covered by peatlands at the beginning of the HTM $(\sim 11 \mathrm{ka})$ (Fig. 9). During the HTM (11-9 ka), boreal deciduous broadleaf and boreal evergreen needleleaf and mixed forests expanded (Fig. 8b and c). Coastal tundra (moist wet tundra) covered north of the Brooks Range between 11 and $10 \mathrm{ka}$, where SP continued its expansion (Fig. 8b). Sphagnum-black spruce forested peatland began forming in the southwestern coast and eastern interior regions, with a rapid increase in total peatland area to about $13 \times 10^{5} \mathrm{~km}^{2}$ (Fig. 9). At 10-9 ka, boreal deciduous forest expanded to north of the Brooks Range, making forest the dominant biome in Alaska (Fig. 2c). Prevailing forest ecosystems indicated a large expansion of peatland, with SBP covering the interior of Alaska (Fig. 8c). During the mid-Holocene (9-5 ka), the terrestrial landscape generally resembled present-day ecosystems (Bigelow et al., 2003). Boreal evergreen needleleaf and mixed forest prevailed in southern and interior Alaska, with tundra returning to north of the Brooks Range and western Alaska (Fig. 2d and e). Although SP kept forming towards the west, some areas dominated by SBP in interior Alaska ceased accumulating C (Fig. 8d). At 5k-19th, almost all the peatlands have formed, 


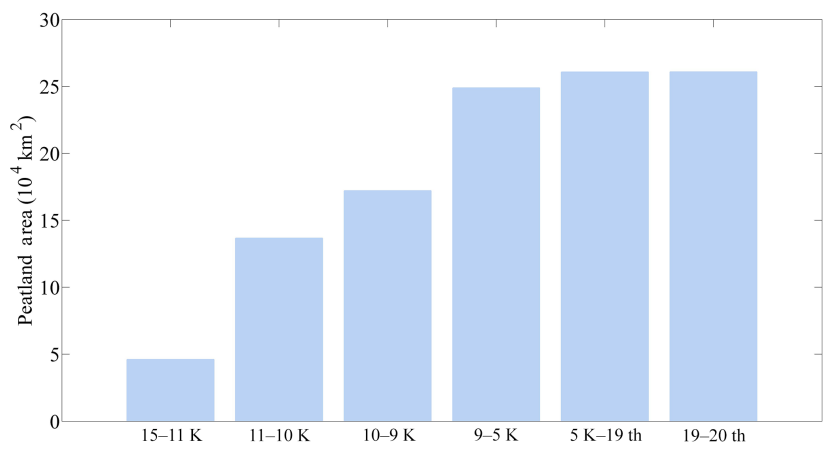

Figure 9. Peatland expansion area $\left(10^{4} \mathrm{~km}^{2}\right)$ in different time slices.

with some interior regions exhibiting a $\mathrm{C}$ loss (Fig. 8e). C accumulation increased again in the last century, averaging about $20 \mathrm{~kg} \mathrm{C} \mathrm{m}^{-2} \mathrm{kyr}^{-1}$ (Fig. 8f). We found that the distribution of SOC densities of both upland and peatland varied greatly depending on the vegetation distribution within each time slice, indicating that vegetation composition might be a major factor controlling regional $\mathrm{C}$ dynamics.

An average peat SOC "apparent" accumulation rate of

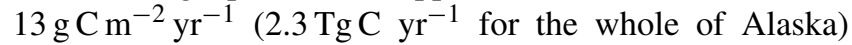
was estimated from $15 \mathrm{ka}$ to $2000 \mathrm{AD}$ (Fig. 10), lower than $18.6 \mathrm{~g} \mathrm{C} \mathrm{m}^{-2} \mathrm{yr}^{-1}$ as estimated from peat cores for northern peatlands (Yu et al., 2010), and slightly higher than the observed rate of $13.2 \mathrm{~g} \mathrm{C} \mathrm{m}^{-2} \mathrm{yr}^{-1}$ from four peatlands in Alaska (Jones and Yu, 2010). A simulated peak occurred during the HTM with the rate $29.1 \mathrm{~g} \mathrm{C} \mathrm{m}^{-2} \mathrm{yr}^{-1}\left(5.1 \mathrm{Tg} \mathrm{C} \mathrm{yr}^{-1}\right)$, which was slightly higher than the observed $25 \mathrm{~g} \mathrm{C} \mathrm{m}^{-2} \mathrm{yr}^{-1}$ for northern peatlands and $\sim 20 \mathrm{~g} \mathrm{C} \mathrm{m}^{-2} \mathrm{yr}^{-1}$ for Alaska (Yu et al., 2010). It was almost 4 times higher than the rate $6.9 \mathrm{~g} \mathrm{C} \mathrm{m}^{-2} \mathrm{yr}^{-1}\left(1.4 \mathrm{TgC}^{-1}\right)$ over the rest of the Holocene, which corresponded to the peat-core-based observations of $\sim 5 \mathrm{~g} \mathrm{C} \mathrm{m}^{-2} \mathrm{yr}^{-1}$. The mid and late Holocene showed much slower $\mathrm{C}$ accumulation at a rate of approximately 5-fold lower than during the HTM. This corresponded to the observation of a 6-fold decrease in the rate of new peatland formation after $8.6 \mathrm{ka}$ (Jones and $\mathrm{Yu}, 2010$ ). The $\mathrm{C}$ accumulation rates increased abruptly to $39.2 \mathrm{~g} \mathrm{C} \mathrm{m}^{-2} \mathrm{yr}^{-1}$ during the last century, within the field-measured average apparent rate range of $20-50 \mathrm{~g} \mathrm{C} \mathrm{m}^{-2} \mathrm{yr}^{-1}$ over the last 2000 years (Yu et al., 2010).

The SOC stock of northern peatlands has been estimated in many studies, ranging from 210 to $621 \mathrm{Pg}$ (Oechel, 1989; Gorham, 1991; Armentano and Menges, 1986; Turunen et al., 2002; Yu et al., 2010; see Yu, 2012, for a review). Assuming Alaskan peatlands were representative of northern peatlands and using the area of Alaskan peatlands $(0.45 \times$ $10^{6} \mathrm{~km}^{2}$; Kivinen and Pakarinen, 1981) divided by the total area of northern peatlands $\left(\sim 4 \times 10^{6} \mathrm{~km}^{2}\right.$; Maltby and Immirzi, 1993), we estimated a SOC stock of 23.6-69.9 Pg C for Alaskan peatlands. Our model estimated $27-48 \mathrm{PgC}$

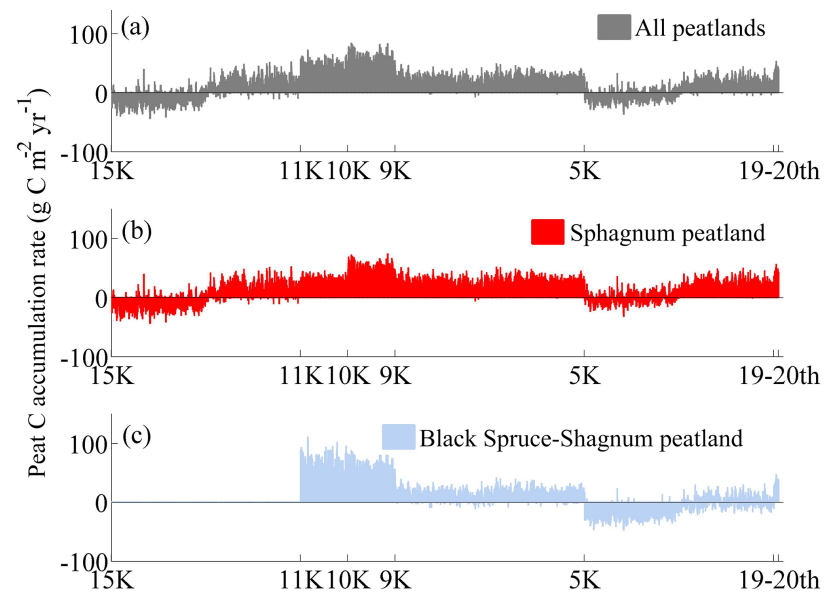

Figure 10. Bars of peatland mean $\mathrm{C}$ accumulation rates from $15 \mathrm{ka}$ to $2000 \mathrm{AD}$ for (a) the weighted average of all peatlands, (b) Sphagnum open peatlands, and (c) Sphagnum-black spruce peatlands.

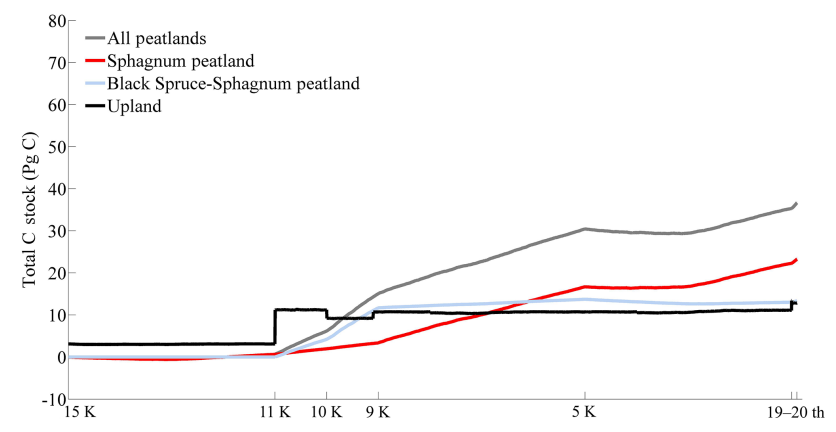

Figure 11. Total C stock accumulated from $15 \mathrm{ka}$ to $2000 \mathrm{AD}$ for all peatlands, Sphagnum open peatlands, Sphagnum-black spruce peatlands, and upland soils.

(23.9 Pg C in SP and 13.5 Pg C in SBP) had been accumulated from $15 \mathrm{ka}$ to $2000 \mathrm{AD}$ (Fig. 11), due to uncertain parameters (Table 2; see Wang et al., 2016, for model parameters). The uncertainty can also have resulted from peat basal age distributions and the estimation of total peatland area using modern inundation data as discussed above. By incorporating the observed basal age distribution to determine the expansion of peatland through time, we estimated that approximately $68 \%$ of Alaskan peatlands had formed by the end of the HTM, similar to the estimation from observed basal peat ages that $75 \%$ peatlands had formed by $8.6 \mathrm{ka}$ (Jones and $\mathrm{Yu}$, 2010).

The northern circumpolar soils were estimated to cover approximately $18.78 \times 10^{6} \mathrm{~km}^{2}$ (Tarnocai et al., 2009). The non-peatland soil $\mathrm{C}$ stock was estimated to be in the range of 150-191 Pg C for boreal forests (Apps et al., 1993; Jobbágy and Jackson, 2000) and 60-144 Pg C for tundra in the 0-100 cm depth (Apps et al., 1993; Gilmanov and Oechel, 1995; Oechel et al., 1993); $1.24 \times 10^{6} \mathrm{~km}^{2}$ non-peatland area was estimated from the total land area of Alaska $(1.69 \times$ 

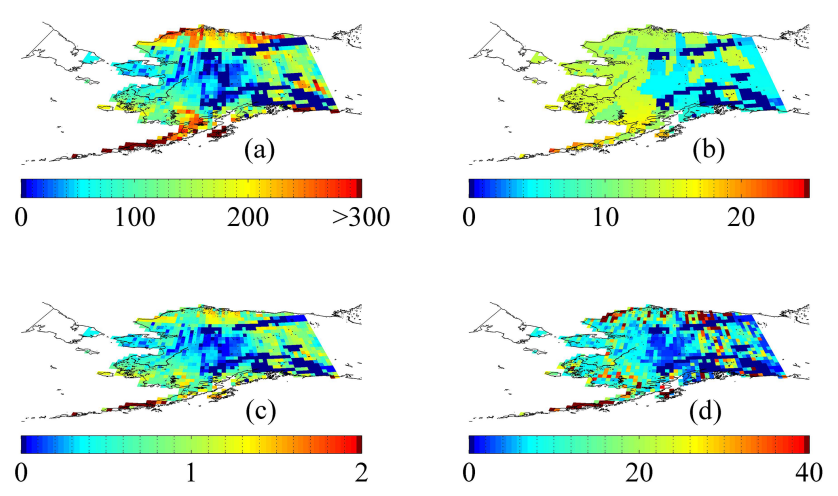

Figure 12. Spatial distribution of (a) total peat SOC density $\left(\mathrm{kg} \mathrm{C} \mathrm{m}^{-2}\right)$, (b) total mineral SOC density $\left(\mathrm{kg} \mathrm{C} \mathrm{m}^{-2}\right)$, (c) total peat depth $(\mathrm{m})$, and (d) area-weighted total (peatlands plus non-peatlands) SOC density $\left(\mathrm{kg} \mathrm{C} \mathrm{m}^{-2}\right)$ in Alaska from $15 \mathrm{ka}$ to $2000 \mathrm{AD}$.

$10^{6} \mathrm{~km}^{2}$ ). Therefore, Alaska non-peatland soil contained 17$27 \mathrm{PgC}$ by using the ratio of Alaskan over northern nonpeatland. In comparison, we modeled 9-15 Pg C (within $1 \mathrm{~m}$ depth), depending on the prior ranges of model parameters from Tang and Zhuang (2008).

The simulated modern SOC distribution (Fig. 12c) was largely consistent with the study of Hugelius et al. (2014) (see Fig. 3 in the paper). The model captured the SOC density on the northern and southwestern coasts of Alaska, with most grids $>40 \mathrm{~kg} \mathrm{C} \mathrm{m}^{-2}$ on average. Those regions also showed high SOC density ( $>75 \mathrm{~kg} \mathrm{C} \mathrm{m}^{-2}$ ), which was also exhibited in our result. The eastern part and the western coast had the lowest SOC densities, corresponding to the simulation result that most grids had SOC values between 20 and $40 \mathrm{~kg} \mathrm{C} \mathrm{m}^{-2}$. We estimated an average peat depth of $1.9 \pm 0.8 \mathrm{~m}$ considering the uncertainties within dry bulk densities. It was similar to the observed mean depth of $2.29 \mathrm{~m}$ for Alaskan peatlands (Gorham et al., 1991, 2012). Our estimates (Fig. 12d) showed a relatively high correlation with the 64 observed peat samples, especially with higher depths (Fig. 13) $\left(R^{2}=0.45\right)$. The large intercept of the regression line $(101 \mathrm{~cm})$ suggested that the model might have not performed well in estimating the grids with low peat depths $(<50 \mathrm{~cm})$. The peat characteristics (e.g., bulk density) from location to location may differ greatly, even within the same small region. Thus, it is difficult to capture the observed variations of peat depths, as we used the averaged bulk density of the whole of Alaska.

\subsection{Effects of climate on ecosystem carbon accumulation}

The simulated climate by the ECBilt-CLIO model showed that among the six time periods, the coolest temperature appeared at $15-11 \mathrm{ka}$, followed by the mid and late Holocene (5 ka-1900 AD). Those two periods were also generally dry (Fig. 3f). The former represented colder and drier climates

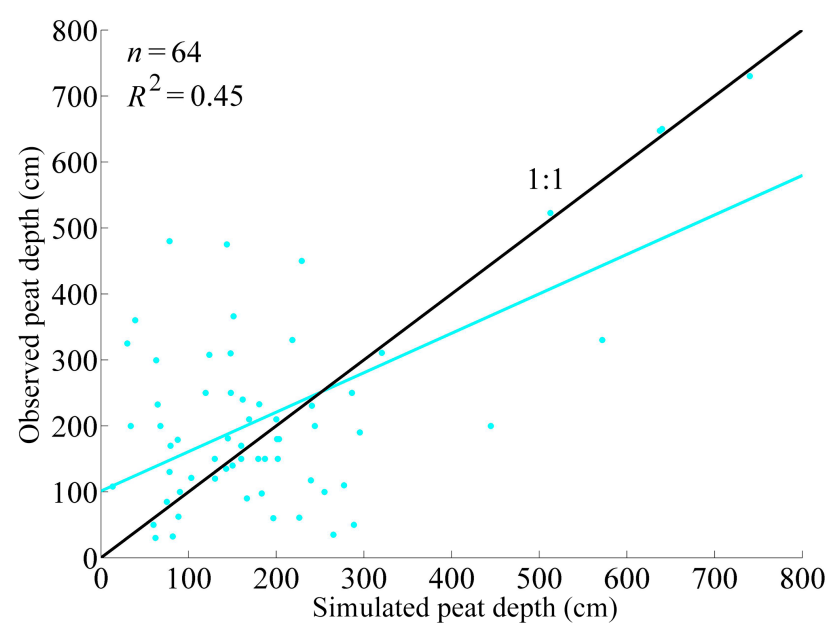

Figure 13. Field-based estimates and model simulations for peat depths in Alaska: the observed and simulated data are extracted from the same grids on the map. The linear regression line (cyan) is compared with the $1: 1$ line. The linear regression is significant $(P<0.001, n=64)$ with $R^{2}=0.45$, slope $=0.65$, and intercept $=101.05 \mathrm{~cm}$. The observations of $>1000 \mathrm{~cm}$ are treated as outliers.

before the onset of the Holocene and the HTM (Barber and Finney, 2000; Edwards et al., 2001). The latter represented post-HTM neoglacial cooling, which has caused permafrost aggradation across northern high latitudes (Oksanen et al., 2001; Zoltai, 1995).

Despite the relatively large inter-annual NPP variation that resulted from the annual fluctuations of the climate forcing (Fig. 5b), the long-term NPP, vegetation $\mathrm{C}$ density and storage were highest during the HTM (Fig. 5a and c). Annual $\mathrm{C}$ accumulation rates also reached their peak (Figs. 511). The long-term variation of NPP has a similar pattern of the climate (see Fig. 3 for climate variables), where higher NPP, along with higher vegetation $C$, coincided with warmer temperatures and enhanced precipitation during the HTM compared to other time periods. ECBilt-CLIO simulated a warmest summer and a prolonged growing season, leading to a stronger seasonality of temperature during the HTM (Kaufman et al., 2004, 2016), in line with the orbitally induced maximum summer insolation (Berger and Loutre, 1991; Renssen et al., 2009). The coincidence between the highest vegetation $\mathrm{C}$ uptake and SOC accumulation rates and the warmest summer and the wetter-thanbefore conditions indicated a strong link between those climate variables and $\mathrm{C}$ dynamics in Alaska. Enhanced climate seasonality characterized by warmer summer, enhanced summer precipitation and possibly earlier snowmelt during the HTM accelerated the photosynthesis and subsequently increased NPP (Tucker et al., 2001; Kimball et al., 2004; Linderholm, 2006). As shown in our sensitivity test, annual NPP was increased by 40 and $20 \mathrm{~g} \mathrm{C} \mathrm{m}^{-2} \mathrm{yr}^{-1}$ under the warmer and wetter scenarios, respectively (Fig. 14a, b). Meanwhile, 

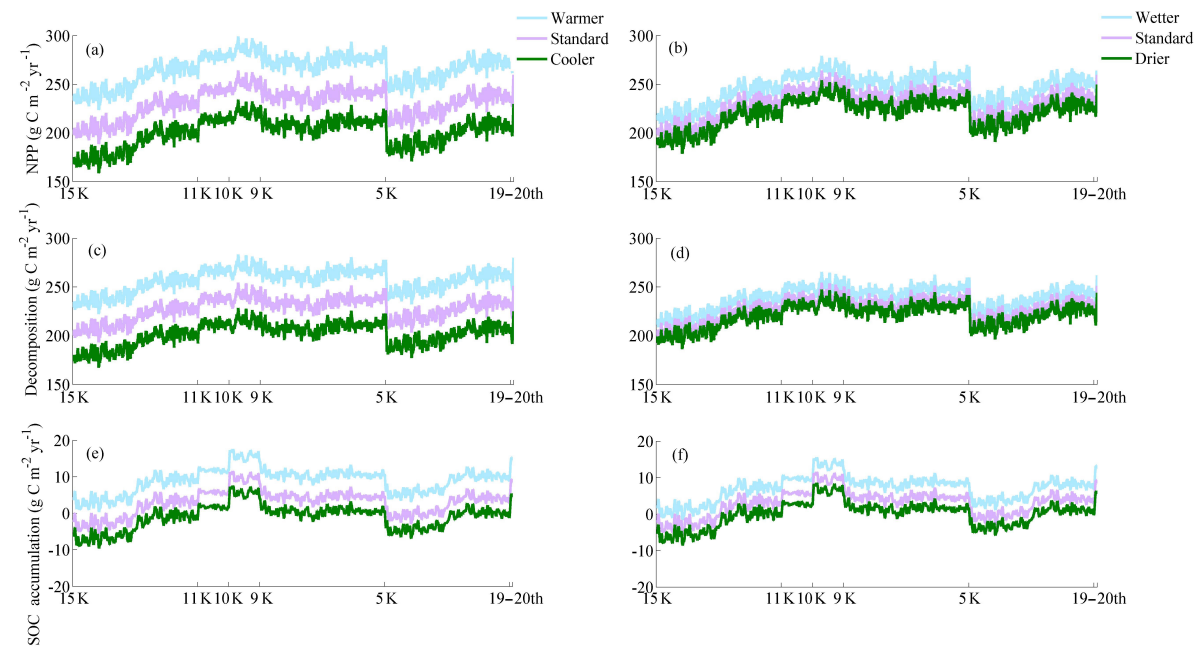

Figure 14. Temperature and precipitation effects on (a, b) annual NPP, (c, d) annual SOC decomposition rate (aerobic plus anaerobic), and $(\mathbf{e}, \mathbf{f})$ the annual SOC accumulation rate of Alaska. A 10-year moving average was applied.

warmer condition could positively affect the SOC decomposition (Nobrega et al., 2007). However, it could be offset to a certain extent via the hydrological effect, as higher precipitation could raise the water-table position, allowing less space for aerobic heterotrophic respiration. Our sensitivity test results indicated that warmer and wetter conditions could lead to an increase in decomposition of up to 35 and $15 \mathrm{~g} \mathrm{C} \mathrm{m}^{-2} \mathrm{yr}^{-1}$, respectively (Fig. 14c, d). We did not find a decrease in total heterotrophic respiration throughout Alaska from the higher precipitation. It was presumably due to a much larger area of upland soils $\left(1.3 \times 10^{6} \mathrm{~km}^{2}\right)$ than peatland soils $\left(0.26 \times 10^{6} \mathrm{~km}^{2}\right)$, as higher precipitation would cause higher aerobic respiration in the unsaturated zone of upland soils and consequently stimulate the SOC decomposition. The relatively low NPP and vegetation C density, along with the lower total soil $\mathrm{C}$ stocks, were consistent with the unfavorable cool and dry climate conditions at 15-11 ka and during the mid and late Holocene. Statistical analysis indicated that temperature had the most significant effect on peat SOC accumulation rate, followed by the seasonality of NIRR (Wang et al., 2016). The seasonality of temperature, the interaction of temperature and precipitation, and precipitation alone also showed significance. The strong link between climate factors and $\mathrm{C}$ dynamics may explain the lower SOC accumulation during the neoglacier cooling period (Marcott et al., 2013; Vitt et al., 2000; Peteet et al., 1998; Yu et al., 2010). The rapid peat SOC accumulation during the 20th century under warming and wetter climate may suggest a continuous C sink in this century, as concluded in Spahni et al. (2013). However, the rising temperature in the future may have positive effects on heterotrophic respiration and simultaneously increase evapotranspiration and lower the water table. This could increase aerobic decomposition and thus switch the Alaskan peatland from a $\mathrm{C}$ sink into a $\mathrm{C}$ source.
Moreover, the increasing anthropogenic activities including land use will probably increase drought and subsequently enhance the risk of fire, releasing carbon to the atmosphere. The fate of Alaskan SOC stock and the biogeochemical cycling of the terrestrial ecosystems under future scenarios need further investigation.

\subsection{Effects of vegetation distribution on ecosystem carbon accumulation}

Climate variables significantly affect $\mathrm{C}$ dynamics within each time slice. However, different vegetation distributions during various periods led to clear step changes, suggesting vegetation composition was likely to be another primary factor (Figs. 6, 7, 8, and 11). As key parameters controlling C dynamics in the model (e.g., maximum rate of photosynthesis, litter fall C, maximum rate of monthly NPP) are ecosystem type specific, vegetation distribution changes may drastically affect regional plant productivity and $\mathrm{C}$ storage. Our sensitivity test indicated that by replacing all vegetation types with forests, there was a total increase of $36.9 \mathrm{Pg}$ in upland plus peatland soils. There was also an increase of $48.8 \mathrm{PgC}$ under warmer and wetter conditions, suggesting that both climate and vegetation distribution may have played important roles in carbon accumulation.

The vegetation changes reconstructed from fossil pollen data during different time periods followed the general climate history during the last 15000 years. For instance, the migration of dark boreal forests over snow-covered tundra during the HTM was probably induced by the warmer and wetter climate that resulted from the insolation changes ( $\mathrm{He}$ et al., 2014). The cooler and drier climate after the midHolocene limited the growth of boreal broadleaf conifers (Prentice et al., 1992), and therefore resulted in the replacement of broadleaf forest with needleleaf forest and tundra 
ecosystems. Since the parameters of our model for individual vegetation type were static, parameterizing the model using modern site-level observations might have introduced uncertainty to parameters, which may result in regional simulation uncertainties. Assuming each parameter as constant (e.g., the lowest water-table boundary; see Wang et al., 2016, for details) over time may also weaken the model's response to different climate scenarios. Furthermore, applying static vegetation maps at millennial scales and using modern elevation and $\mathrm{pH}$ data may simplify the complicated changes in landscape and terrestrial ecosystems, as vegetation can shift within hundreds of years (Ager and Brubake, 1985; see $\mathrm{He}$ et al., 2014, discussion section). Relatively coarse spatial resolution $\left(0.5^{\circ} \times 0.5^{\circ}\right)$ in P-TEM simulations may also introduce uncertainties. In addition, because we used the modern inundation map to delineate the peatland and upland within each grid cell, we might have overestimated the total peatland area since not all inundated areas are peatlands. Linking field-estimated basal ages of peat cores to the vegetation types during each period involves large uncertainties due to the limitation of the peat classification and insufficient peat samples. Thus, the estimated spatially explicit basal age data shall also introduce a large uncertainty to our regional quantification of carbon accumulation.

\section{Conclusions}

We used a biogeochemistry model for both peatland and nonpeatland ecosystems to quantify the $\mathrm{C}$ stock and its changes over time in Alaskan terrestrial ecosystems during the last 15000 years. The simulated peat SOC accumulation rates were compared with peat-core data from four peatlands on the Kenai Peninsula in southern Alaska. The model estimated the peat SOC accumulation rate trajectory throughout the Holocene well. Our regional simulation showed that 36-63 Pg C had been accumulated in Alaskan land ecosystems starting 15000 years ago, including $27-48 \mathrm{Pg} \mathrm{C}$ in peatlands and $9-15 \mathrm{PgC}$ in non-peatlands (within $1 \mathrm{~m}$ depth). We also estimated that $2.5-3.7 \mathrm{PgC}$ was stored in contemporary Alaskan vegetation, with $0.3-0.6 \mathrm{PgC}$ in peatlands and $2.2-3.1 \mathrm{PgC}$ in non-peatlands. The estimated average rate of peat $\mathrm{C}$ accumulation was $2.3 \mathrm{TgC} \mathrm{yr}^{-1}$ with a peak (5.1 $\mathrm{Pg} \mathrm{C} \mathrm{yr}^{-1}$ ) in the HTM, 4-fold higher than the rate of 1.4 $\mathrm{Pg} \mathrm{C} \mathrm{yr}^{-1}$ over the rest of the Holocene. The 20th century represented another high SOC accumulation period after a much lower accumulation period of the late Holocene. We estimated an average depth of $1.9 \mathrm{~m}$ of peat in current Alaskan peatlands, similar to the observed mean depth. The changes in vegetation distribution were found to be the major control on the spatial variations of SOC accumulation in different time periods. The warming in the HTM characterized by the increased summer temperature and increased seasonality of solar radiation, as well as the higher precipitation, might have played an important role in the high $\mathrm{C}$ accumulation.

\section{Data availability}

Data presented in this paper are publicly accessible: ECBilt-CLIO Paleosimulation (http: //apdrc.soest.hawaii.edu/datadoc/sim2bl.php), $\quad$ CRU2.0 (http://www.cru.uea.ac.uk/data). Model parameter data and the model evaluation process are in Wang et al. (2016). Other simulation data including model codes are available upon request from the corresponding author (qzhuang@ @urdue.edu).

Acknowledgements. We acknowledge the funding support from NSF project IIS-1027955 and DOE project DE-SC0008092. We also acknowledge the SPRUCE project for allowing us to use its data.

Edited by: A. V. Eliseev

Reviewed by: two anonymous referees

\section{References}

Ager, T. A. and Brubaker, L.: Quaternary palynology and vegetational history of Alaska, in: Pollen Records of Late Quaternary North American Sediments, American Association of Stratigraphic Palynologists (AASP) Foundation, Dallas, Texas, USA, 353-384, 1985.

Apps, M. J., Kurz, W. A., Luxmoore, R. J., Nilsson, L. O., Sedjo, R. A., Schmidt, R., Simpson, L. G., and Vinson, T. S.: Boreal forests and tundra, Water Air Soil Poll., 70, 39-53, 1993.

Armentano, T. V. and Menges, E. S.: Patterns of change in the carbon balance of organic soil-wetlands of the temperate zone, J. Ecol., 755-774, 1986.

Balshi, M. S., McGuire, A. D., Zhuang, Q., Melillo, J., Kicklighter, D. W., Kasischke, E., Wirth, C., Flannigan, M., Harden, J., Clein, J. S., Burnside, T. J., McAllister, J., Kurz, W. A., Apps, M., and Shvidenko, A.: The role of historical fire disturbance in the carbon dynamics of the pan-boreal region: A process-based analysis, J. Geophys. Res.-Biogeo., 112, G02029, doi:10.1029/2006JG000380, 2007

Barber, V. A. and Finney, B. P.: Late Quaternary paleoclimatic reconstructions for interior Alaska based on paleolake-level data and hydrologic models, J. Paleolimnol., 24, 29-41, 2000.

Belyea, L. R.: Nonlinear dynamics of peatlands and potential feedbacks on the climate system, in: Carbon cycling in northern peatlands, American Geophysical Union, Washington, DC, 5-18, 2009.

Berger, A. and Loutre, M. F.: Insolation values for the climate of the last 10 million years, Quaternary Sci Rev., 10, 297-317, 1991.

Bigelow, N. H., Brubaker, L. B., Edwards, M. E., Harrison, S. P., Prentice, I. C., Anderson, P. M., Andreev, A. A., Bartlein, P. J., Christensen, T. R., Cramer, W., Kaplan, J. O., Lozhkin, A. V., Matveyeva, N. V., Murray, D. F., McGuire, A. D., Razzhivin, V. 
Y., Ritchie, J. C., Smith, B., Walker, D. A., Gajewski, K., Wolf, V., Holmqvist, B. H., Igarashi, Y., Kremenetskii, K., Paus, A., Pisaric, M. F. J., and Volkova, V. S.: Climate change and Arctic ecosystems: 1. Vegetation changes north of $55^{\circ} \mathrm{N}$ between the last glacial maximum, mid-Holocene, and present, J. Geophys. Res.-Atmos., 108, 8170, doi:10.1029/2002JD002558, 2003.

Bridgham, S. D., Megonigal, J. P., Keller, J. K., Bliss, N. B., and Trettin, C.: The carbon balance of North American wetlands, Wetlands, 26, 889-916, 2006.

Carter, A. J. and Scholes, R. J.: SoilData v2.0: generating a global database of soil properties, Environmentek CSIR, Pretoria, South Africa, 2000.

Chivers, M. R., Turetsky, M. R., Waddington, J. M., Harden, J. W., and McGuire, A. D.: Effects of experimental water table and temperature manipulations on ecosystem $\mathrm{CO}_{2}$ fluxes in an Alaskan rich fen, Ecosystems, 12, 1329-1342, 2009.

Churchill, A.: The response of plant community structure and productivity to changes in hydrology in Alaskan boreal peatlands, Master Thesis, University of Alaska, Fairbanks, AK, USA, 119 pp., 2011.

Conrad, R.: Contribution of hydrogen to methane production and control of hydrogen concentrations in methanogenic soils and sediments, FEMS Microbiol. Ecol., 28, 193-202, 1999.

Davidson, E. A. and Janssens, I. A.: Temperature sensitivity of soil carbon decomposition and feedbacks to climate change, Nature, 440, 165-173, 2006.

Davidson, E. A., Trumbore, S. E., and Amundson, R.: Biogeochemistry: soil warming and organic carbon content, Nature, 408, 789-790, 2000.

Edwards, M. E., Mock, C. J., Finney, B. P., Barber, V. A., and Bartlein, P. J.: Potential analogues for paleoclimatic variations in eastern interior Alaska during the past 14,000 yr: atmosphericcirculation controls of regional temperature and moisture responses, Quaternary Sci. Rev., 20, 189-202, 2001.

Euskirchen, E. S., McGuire, A. D., and Chapin, F. S.: Energy feedbacks of northern high-latitude ecosystems to the climate system due to reduced snow cover during 20th century warming, Glob. Change Biol., 13, 2425-2438, 2007.

Frolking, S., Roulet, N. T., Tuittila, E., Bubier, J. L., Quillet, A., Talbot, J., and Richard, P. J. H.: A new model of Holocene peatland net primary production, decomposition, water balance, and peat accumulation, Earth Syst. Dynam., 1, 1-21, doi:10.5194/esd-11-2010, 2010.

Frolking, S., Talbot, J., Jones, M. C., Treat, C. C., Kauffman, J. B., Tuittila, E. S., and Roulet, N.: Peatlands in the Earth's 21st century climate system, Environ. Rev., 19, 371-396, 2011.

Gilmanov, T. G. and Oechel, W. C.: New estimates of organic matter reserves and net primary productivity of the North American tundra ecosystems, J. Biogeogr., 22, 723-741, doi:10.2307/2845975, 1995.

Gorham, E.: Biotic impoverishment in northern peatlands, in: The earth in transition: patterns and processes of biotic impoverishment, Cambridge University Press, Cambridge, UK, 65-98, 1990.

Gorham, E.: Northern peatlands: role in the carbon cycle and probable responses to climatic warming, Ecol. Appl., 1, 182-195, 1991.
Gorham, E., Lehman, C., Dyke, A., Clymo, D., and Janssens, J.: Long-term carbon sequestration in North American peatlands, Quaternary Sci. Rev., 58, 77-82, 2012.

He, Y., Jones, M. C., Zhuang, Q., Bochicchio, C., Felzer, B. S., Mason, E., and $\mathrm{Yu}, \mathrm{Z}$.: Evaluating $\mathrm{CO}_{2}$ and $\mathrm{CH}_{4}$ dynamics of Alaskan ecosystems during the Holocene Thermal Maximum, Quaternary Sci. Rev., 86, 63-77, 2014.

Hinzman, L. D., Viereck, L. A., Adams, P. C., Romanovsky, V. E., and Yoshikawa, K.: Climate and permafrost dynamics of the Alaskan boreal forest, in: Alaska's Changing Boreal Forest, 3961, 2006.

Hobbie, S. E.: Interactions between litter lignin and nitrogenitter lignin and soil nitrogen availability during leaf litter decomposition in a Hawaiian montane forest, Ecosystems, 3, 484-494, 2000.

Hugelius, G., Strauss, J., Zubrzycki, S., Harden, J. W., Schuur, E. A. G., Ping, C.-L., Schirrmeister, L., Grosse, G., Michaelson, G. J., Koven, C. D., O’Donnell, J. A., Elberling, B., Mishra, U., Camill, P., Yu, Z., Palmtag, J., and Kuhry, P.: Estimated stocks of circumpolar permafrost carbon with quantified uncertainty ranges and identified data gaps, Biogeosciences, 11, 6573-6593, doi:10.5194/bg-11-6573-2014, 2014.

IPCC: The Physical Science Basis, Contribution of Working Group I to the Fifth Assessment Report of the Intergovernmental Panel on Climate Change, Cambridge University Press, Cambridge, UK, New York, NY, p. 1535, 2013.

IPCC: Mitigation of Climate Change, Contribution of Working Group III to the Fifth Assessment Report of the Intergovernmental Panel on Climate Change, Cambridge University Press, Cambridge, UK, New York, NY, 2014.

Jobbágy, E. G. and Jackson, R. B.: The vertical distribution of soil organic carbon and its relation to climate and vegetation, Ecol. Appl., 10, 423-436, 2000.

Jones, M. C. and Yu, Z.: Rapid deglacial and early Holocene expansion of peatlands in Alaska, P. Natl. Acad. Sci. USA, 107, 7347-7352, 2010.

Jones, P. D. and Moberg, A.: Hemispheric and large-scale surface air temperature variations: An extensive revision and an update to 2001, J. Climate, 16, 206-223, 2003.

Juday, G. P.: Forests, land management and agriculture, in: Arctic Climate Impact Assessment, 781-862, 2005.

Kane, E. S., Turetsky, M. R., Harden, J. W., McGuire, A. D., and Waddington, J. M.: Seasonal ice and hydrologic controls on dissolved organic carbon and nitrogen concentrations in a boreal-rich fen, J. Geophys. Res.-Biogeo., 115, G04012, doi:10.1029/2010JG001366, 2010.

Kaufman, D. S., Ager, T. A., Anderson, N. J., Anderson, P. M., Andrews, J. T., Bartlein, P. J., Brubaker, L. B., Coats, L. L., Cwynar, L. C., Duvall, M. L., Dyke, A. S., Edwards, M. E., Eisner, W. R., Gajewski, K., Geirsdottir, A., Hu, F. S., Jennings, A. E., Kaplan, M. R., Kerwin, M. W., Lozhkin, A. V., MacDonald, G. M., Miller, G. H., Mock, C. J., Oswald, W. W., Otto-Bliesner, B. L., Porinchu, D. F., Ruhland, K., Smol, J. P., Steig, E. J., and Wolfe, B. B.: Holocene thermal maximum in the western Arctic (0-180 W), Quaternary Sci. Rev., 23, 529-560, 2004.

Kaufman, D. S., Axford, Y. L., Henerson, A., McKay, N. P., Oswald, W. W., Saenger, C., Anderson, R. S., Bailey, H. L., Clegg, B., Gajewski, K., Hu, F. S., Jones, M. C., Massa, C., Routson, C. C., Werner, A., Wooller, M. J., and Yu, Z.: Holocene climate 
changes in eastern Beringia (NW North America) - a systemic review of multi-proxy evidence, Quaternary Sci. Rev., 147, 312339, doi:10.1016/j.quascirev.2015.10.021, 2016.

Keller, J. K. and Bridgham, S. D.: Pathways of anaerobic carbon cycling across an ombrotrophic-minerotrophic peatland gradient, Limnol. Oceanogr., 52, 96-107, doi:10.4319/lo.2007.52.1.0096, 2007.

Keller, J. K. and Takagi, K. K.: Solid-phase organic matter reduction regulates anaerobic decomposition in bog soil, Ecosphere, 4, 112, 2013.

Kimball, J. S., McDonald, K. C., Running, S. W., and Frolking, S. E.: Satellite radar remote sensing of seasonal growing seasons for boreal and subalpine evergreen forests, Remote Sens. Environ., 90, 243-258, 2004.

Kivinen, E. and Pakarinen, P.: Geographical distribution of peat resources and major peatland complex types in the world, Ann. Acad. Sci. Fenn. A1, 132, 1-28, 1981.

Kleinen, T., Brovkin, V., and Schuldt, R. J.: A dynamic model of wetland extent and peat accumulation: results for the Holocene, Biogeosciences, 9, 235-248, doi:10.5194/bg-9-235-2012, 2012.

Kuhry, P. and Vitt, D. H.: Fossil carbon / nitrogen ratios as a measure of peat decomposition, Ecology, 77, 271-275, 1996.

Linderholm, H. W.: Growing season changes in the last century, Agr. Forest Meteorol., 137, 1-14, 2006.

Loisel, J., Gallego-Sala, A. V., and Yu, Z.: Global-scale pattern of peatland Sphagnum growth driven by photosynthetically active radiation and growing season length, Biogeosciences, 9, 27372746, doi:10.5194/bg-9-2737-2012, 2012.

Loisel, J., Yu, Z., Beilman, D. W., Camill, P., Alm, J., Amesbury, M. J.: A database and synthesis of northern peatland soil properties and Holocene carbon and nitrogen accumulation, Holocene, 0959683614538073, doi:10.1177/0959683614538073, 2014.

Maltby, E. and Immirzi, P.: Carbon dynamics in peatlands and other wetland soils regional and global perspectives, Chemosphere, 27, 999-1023, 1993.

Manabe, S. and Wetherald, R. T.: On the distribution of climate change resulting from an increase in $\mathrm{CO}_{2}$ content of the atmosphere, J. Atmos. Sci., 37, 99-118, 1980.

Manabe, S. and Wetherald, R. T.: Reduction in summer soil wetness induced by an increase in atmospheric carbon dioxide, Science, 232, 626-628, 1986.

Marcott, S. A., Shakun, J. D., Clark, P. U., and Mix, A. C.: A reconstruction of regional and global temperature for the past 11,300 years, Science, 339, 1198-1201, 2013.

Matthews, E. and Fung, I.: Methane emission from natural wetlands: Global distribution, area, and environmental characteristics of sources, Global Biogeochem. Cy., 1, 61-86, 1987.

McGuire, A. D. and Hobbie, J. E.: Global climate change and the equilibrium responses of carbon storage in arctic and subarctic regions, in: Modeling the Arctic system: A workshop report on the state of modeling in the Arctic System Science program, 5354, 1997.

McGuire, A. D., Melillo, J. M., Kicklighter, D. W., and Joyce, L. A.: Equilibrium responses of soil carbon to climate change: empirical and process-based estimates, J. Biogeogr., 785-796, 1995.

McGuire, A. D., Anderson, L. G., Christensen, T. R., Dallimore, S., Guo, L., Hayes, D. J., Heimann, M., Lorenson, T. D., MacDonald, R. W., and Roulet, N.: Sensitivity of the carbon cycle in the Arctic to climate change, Ecol. Monogr., 79, 523-555, 2009.
Melillo, J. M., Kicklighter, D. W., McGuire, A. D., Peterjohn, W. T., and Newkirk, K.: Global change and its effects on soil organic carbon stocks, in: Dahlem Conference Proceedings, John Wiley and Sons, New York, Chichster, 175-189, 1995.

Mitchell, T. D., Carter, T. R., Jones, P. D., Hulme, M., and New, M.: A comprehensive set of high-resolution grids of monthly climate for Europe and the globe: the observed record (1901-2000) and 16 scenarios (2001-2100), Tyndall centre for climate change research working paper no. 55, 25 pp., 2004.

Moore, T. R., Bubier, J. L., Frolking, S. E., Lafleur, P. M., and Roulet, N. T.: Plant biomass and production and $\mathrm{CO}_{2}$ exchange in an ombrotrophic bog, J. Ecology, 90, 25-36, 2002.

Nobrega, S. and Grogan, P.: Deeper snow enhances winter respiration from both plant-associated and bulk soil carbon pools in birch hummock tundra, Ecosystems, 10, 419-431, 2007.

Oechel, W. C.: Nutrient and water flux in a small arctic watershed: an overview, Holarctic Ecol., 229-237, 1989.

Oechel, W. C., Hastings, S. J., Vourlrtis, G., Jenkins, M., Riechers, G., and Grulke, N.: Recent change of Arctic tundra ecosystems from a net carbon dioxide sink to a source, Nature, 361, 520-523, 1993.

Oksanen, P. O., Kuhry, P., and Alekseeva, R. N.: Holocene development of the Rogovaya river peat plateau, European Russian Arctic, Holocene, 11, 25-40, 2001.

Peteet, D., Andreev, A., Bardeen, W., and Mistretta, F.: Long-term Arctic peatland dynamics, vegetation and climate history of the Pur-Taz region, western Siberia, Boreas, 27, 115-126, 1998.

Prentice, I. C., Cramer, W., Harrison, S. P., Leemans, R., Monserud, R. A., and Solomon, A. M.: Special paper: a global biome model based on plant physiology and dominance, soil properties and climate, J. Biogeogr., 117-134, 1992.

Raich, J. W., Rastetter, E. B., Melillo, J. M., Kicklighter, D. W., Steudler, P. A., Peterson, B. J., Grace, A. L., Moore 1ll, B., and Vorosmarty, C. J.: Potential net primary productivity in South America: application of a global model, Ecol. Appl., 1, 399-429, 1991.

Renssen, H., Seppä, H., Heiri, O., Roche, D. M., Goosse, H., and Fichefet, T.: The spatial and temporal complexity of the Holocene thermal maximum, Nat. Geosci., 2, 411-414, 2009.

Roulet, N. T., Lafleur, P. M., Richard, P. J., Moore, T. R., Humphreys, E. R., and Bubier, J. I. L. L.: Contemporary carbon balance and late Holocene carbon accumulation in a northern peatland, Glob. Change Biol., 13, 397-411, 2007.

Saarinen, T.: Biomass and production of two vascular plants in a boreal mesotrophic fen, Can. J. Botany, 74, 934-938, 1996.

Schuur, E. A., Bockheim, J., Canadell, J. G., Euskirchen, E., Field, C. B., and Goryachkin, S. V.: Vulnerability of permafrost carbon to climate change: implications for the global carbon cycle, BioScience, 58, 701-714, 2008.

Sitch, S., Smith, B., Prentice, I. C., Arneth, A., Bondeau, A., Cramer, W., Kaplan, J. O., Levis, S., Lucht, W., Sykes, M. T., Thonicke, K., and Venevsky, S.: Evaluation of ecosystem dynamics, plant geography and terrestrial carbon cycling in the LPJ dynamic global vegetation model, Glob. Change Biol., 9, 161-185, 2003.

Spahni, R., Joos, F., Stocker, B. D., Steinacher, M., and Yu, Z. C.: Transient simulations of the carbon and nitrogen dynamics in northern peatlands: from the Last Glacial Maximum to the 21st 
century, Clim. Past, 9, 1287-1308, doi:10.5194/cp-9-1287-2013, 2013.

Stocker, B. D., Strassmann, K., and Joos, F.: Sensitivity of Holocene atmospheric $\mathrm{CO}_{2}$ and the modern carbon budget to early human land use: analyses with a process-based model, Biogeosciences, 8, 69-88, doi:10.5194/bg-8-69-2011, 2011.

Stocker, B. D., Spahni, R., and Joos, F.: DYPTOP: a costefficient TOPMODEL implementation to simulate sub-grid spatio-temporal dynamics of global wetlands and peatlands, Geosci. Model Dev., 7, 3089-3110, doi:10.5194/gmd-7-30892014, 2014.

Tang, J. and Zhuang, Q.: Equifinality in parameterization of process-based biogeochemistry models: A significant uncertainty source to the estimation of regional carbon dynamics, J. Geophys. Res.-Biogeo., 113, G04010, doi:10.1029/2008JG000757, 2008

Tang, J. and Zhuang, Q.: A global sensitivity analysis and Bayesian inference framework for improving the parameter estimation and prediction of a process-based Terrestrial Ecosystem Model, J. Geophys. Res.-Atmos., 114, D15303, doi:10.1029/2009JD011724, 2009.

Tang, J., Zhuang, Q., Shannon, R. D., and White, J. R.: Quantifying wetland methane emissions with process-based models of different complexities, Biogeosciences, 7, 3817-3837, doi:10.5194/bg-7-3817-2010, 2010.

Tarnocai, C., Canadell, J. G., Schuur, E. A. G., Kuhry, P., Mazhitova, G., and Zimov, S.: Soil organic carbon pools in the northern circumpolar permafrost region, Global Biogeochem. Cy., 23, GB2023, doi:10.1029/2008GB003327, 2009.

Timm, O. and Timmermann, A.: Simulation of the Last 21000 Years Using Accelerated Transient Boundary Conditions, J. Climate, 20, 4377-4401, 2007.

Tucker, C. J., Slayback, D. A., Pinzon, J. E., Los, S. O., Myneni, R. B., and Taylor, M. G.: Higher northern latitude normalized difference vegetation index and growing season trends from 1982 to 1999, Int. J. Biometeorol., 45, 184-190, 2001.

Turetsky, M. R., Treat, C. C., Waldrop, M. P., Waddington, J. M., Harden, J. W., and McGuire, A. D.: Short-term response of methane fluxes and methanogen activity to water table and soil warming manipulations in an Alaskan peatland, J. Geophys. Res.-Biogeo., 113, G00A10, doi:10.1029/2007JG000496, 2008.

Turunen, J., Tomppo, E., Tolonen, K., and Reinikainen, A.: Estimating carbon accumulation rates of undrained mires in Finlandapplication to boreal and subarctic regions, Holocene, 12, 69-80, 2002.

Vitt, D. H., Halsey, L. A., Bauer, I. E., and Campbell, C.: Spatial and temporal trends in carbon storage of peatlands of continental western Canada through the Holocene, Can. J. Earth Sci., 37, 683-693, 2000.

Wang, S., Zhuang, Q., Yu, Z., Bridgham, S., and Keller, J. K.: Quantifying peat carbon accumulation in Alaska using a process-based biogeochemistry model, J. Geophys. Res.-Biogeo., 121, 21722185, doi:10.1002/2016JG003452, 2016.
Xu-Ri, I. and Prentice, C.: Terrestrial nitrogen cycle simulation with a dynamic global vegetation model, Glob. Change Biol., 14, 1745-1764, doi:10.1111/j.1365-2486.2008.01625.x, 2008.

Yu, Z. C.: Northern peatland carbon stocks and dynamics: a review, Biogeosciences, 9, 4071-4085, doi:10.5194/bg-9-40712012, 2012.

Yu, Z., Beilman, D. W., and Jones, M. C.: Sensitivity of northern peatland carbon dynamics to Holocene climate change, in: Carbon cycling in northern peatlands, Geophysical Monograph Series 184, 55-69, 2009.

Yu, Z., Loisel, J., Brosseau, D. P., Beilman, D. W., and Hunt, S. J.: Global peatland dynamics since the Last Glacial Maximum, Geophys. Res. Lett., 37, L13402, doi:10.1029/2010GL043584, 2010.

Zhuang, Q., Romanovsky, V. E., and McGuire, A. D.: Incorporation of a permafrost model into a large-scale ecosystem model: Evaluation of temporal and spatial scaling issues in simulating soil thermal dynamics, J. Geophys. Res.-Atmos., 106, 33649-33670, 2001.

Zhuang, Q., McGuire, A. D., O’Neill, K. P., Harden, J. W., Romanovsky, V. E., and Yarie, J.: Modeling soil thermal and carbon dynamics of a fire chronosequence in interior Alaska, J. Geophys. Res.-Atmos., 107, 2002.

Zhuang, Q., McGuire, A. D., Melillo, J. M., Clein, J. S., Dargaville, R. J., Kicklighter, D. W., Myneni, R. B., Dong, J., Romanovsky, V. E., Harden, J., and Hobbie, J. E.: Carbon cycling in extratropical terrestrial ecosystems of the Northern Hemisphere during the 20th century: a modeling analysis of the influences of soil thermal dynamics, Tellus B, 55, 751-776, 2003.

Zhuang, Q., Melillo, J. M., Kicklighter, D. W., Prinn, R. G., McGuire, A. D., Steudler, P. A., Felzer, B. S., and Hu, S.: Methane fluxes between terrestrial ecosystems and the atmosphere at northern high latitudes during the past century: A retrospective analysis with a process-based biogeochemistry model, Global Biogeochem. Cy., 18, 2004.

Zhuang, Q., Melillo, J. M., McGuire, A. D., Kicklighter, D. W., Prinn, R. G., Steudler, P. A., Felzer, B. S., and Hu, S.: Net emissions of $\mathrm{CH}_{4}$ and $\mathrm{CO}_{2}$ in Alaska: Implications for the region's greenhouse gas budget, Ecol. Appl., 17, 203-212, 2007.

Zhuang, Q., Zhu, X., He, Y., Prigent, C., Melillo, J. M., McGuire, A. D., Prinn, R. G., and Kicklighter, D. W.: Influence of changes in wetland inundation extent on net fluxes of carbon dioxide and methane in northern high latitudes from 1993 to 2004, Environ. Res. Lett., 10, 095009, 2015.

Zimov, S. A., Schuur, E. A., and Chapin III, F. S.: Permafrost and the global carbon budget, Science, 312, 1612-1613, 2006.

Zoltai, S. C.: Permafrost distribution in peatlands of west-central Canada during the Holocene warm period 6000 years BP, Geogr. Phys. Quatern., 49, 45-54, 1995. 